\title{
Moderate Reduction of $\gamma$-Secretase Attenuates Amyloid Burden and Limits Mechanism-Based Liabilities
}

\author{
Tong Li, ${ }^{1}$ Hongjin Wen, ${ }^{1}$ Cory Brayton, ${ }^{4}$ Fiona M. Laird, ${ }^{1}$ Guojun Ma, ${ }^{1}$ Shiwen Peng, ${ }^{1}$ Lisa Placanica, ${ }^{5}$ T. C. Wu, ${ }^{1}$ \\ Barbara J. Crain, ${ }^{1}$ Donald L. Price, ${ }^{1,2,3}$ Charles G. Eberhart, ${ }^{1}$ and Philip C. Wong ${ }^{1,2}$ \\ Departments of ${ }^{1}$ Pathology, ${ }^{2}$ Neuroscience, ${ }^{3}$ Neurology, and ${ }^{4}$ Comparative Medicine, The Johns Hopkins University, School of Medicine, Baltimore, \\ Maryland 21205, and ${ }^{5}$ Molecular Pharmacology and Chemistry Program, Memorial Sloan-Kettering Cancer Center, New York, New York 10021
}

\begin{abstract}
Although $\gamma$-secretase is recognized as a therapeutic target for Alzheimer's disease, side effects associated with strong inhibition of this aspartyl protease raised serious concerns regarding this therapeutic strategy. However, it is not known whether moderate inhibition of this enzyme will allow dissociation of beneficial effects in the CNS from mechanism-based toxicities in the periphery. We tested this possibility by using a series of mice with genetic reduction of $\gamma$-secretase (levels ranging from 25 to $64 \%$ of control mice). Here, we document that even $30 \%$ reduction of $\gamma$-secretase can effectively ameliorate amyloid burden in the CNS. However, global reduction of this enzyme below a threshold level increased the risk of developing squamous cell carcinoma as well as abnormal proliferation of granulocytes in a $\gamma$-secretase dosage-dependent manner. Importantly, we demonstrate that there exists a critical $\gamma$-secretase level that reduces the risk of amyloidosis in the CNS and limits tumorigenesis in epithelia. Our findings suggest that moderate inhibition of $\gamma$-secretase represents an attractive anti-amyloid therapy for Alzheimer's disease.
\end{abstract}

Key words: $\gamma$-secretase; Alzheimer's disease; $\mathrm{A} \beta$ amyloidosis; Notch; squamous cell carcinoma; splenomegaly

\section{Introduction}

Alzheimer's disease (AD), the most common cause of dementia in the elderly, is characterized by the deposition of amyloid plaque and neurofibrillary tangles in the brain (Wong et al., 2005). Despite significant advances made toward our understanding of the pathogenesis of $\mathrm{AD}$, effective mechanism-based therapies are lacking because only symptomatic treatments for this devastating illness are currently available. The "amyloid cascade hypothesis" has led to intense efforts aimed at decreasing the generation of $\beta$-amyloid $\left(\mathrm{A} \beta\right.$ ) peptides (especially $\mathrm{A} \beta_{42}$ ) or increasing their clearance as potential therapeutic strategies for the treatment of AD (Hardy and Selkoe, 2002; Tanzi and Bertram, $2005)$. Because $A \beta$ peptides are generated by sequential processing of the $\beta$-amyloid precursor protein (APP) by $\beta$-secretase and $\gamma$-secretase, these two enzymes represent high-priority targets for drug discoveries in efforts to attenuate $\mathrm{A} \beta$ amyloidosis in $\mathrm{AD}$.

One major concern of targeting $\gamma$-secretase for AD therapy is that inhibition of $\gamma$-secretase is associated with untoward

\footnotetext{
Received May 10, 2007; revised July 24, 2007; accepted Aug. 15, 2007.

This work was supported by National Institute of Neurological Disorders and Stroke Grants R01 NS45150 and P01 NS047308 (P.C.W.), National Institute on Aging Grant P50 AG05146 (D.L.P.), the Alzheimer's Association (P.C.W.), the Rotary CART Fund (P.C.W.), the Adler Foundation (T.L.), and the Ellison Medical Foundation (T.L.). We thank W. Westra and D. Sidranski for their insightful comments; V. Nehus, L. Ding, F. Davenport, K. Eipl, S. Kang, and C. Chang for technical support; Y. M. Li (Memorial Sloan-Kettering Cancer Center) for $\gamma$-secretase inhibitor JC-22; and G. Thinakaran (University of Chicago, Chicago, IL) for PEN-2 antiserum.

Correspondence should be addressed to Philip C. Wong and Tong Li, Department of Pathology, The Johns Hopkin University School of Medicine, 558 Ross Research Building, 720 Rutland Avenue, Baltimore, MD 21205-2196. E-mail: wong@jhmi.edu, tli1@jhmi.edu.

G. Ma's present address: The Laboratory of Molecular Biology, Howard Hughes Medical Institute, The Rockefeller University, New York, NY 10021

DOI:10.1523/JNEUROSCI.2152-07.2007

Copyright $\odot 2007$ Society for Neuroscience $\quad$ 0270-6474/07/2710849-11\$15.00/0
}

mechanism-based side effects. $\gamma$-Secretase, an aspartyl protease comprising presenilin (PS), nicastrin (Nct), anterior pharynx defective-1 (Aph-1), and PS enhancer-2 (Pen-2) (De Strooper, 2003), is an unusual enzyme required for the regulated intramembranous proteolysis of a growing list of type I transmembrane proteins, such as members of the Notch family, which is critical for binary cell fate (Artavanis-Tsakonas et al., 1999), in the differentiation of the intestinal epithelium (Brittan and Wright, 2002), and in lymphopoiesis at multiple steps (Allman et al., 2002) in adult animals. Moreover, Notch can serve either as an oncogene or tumor suppressor in various tumor types depending on gene dosage and temporal or cellular context (Nicolas et al., 2003; Weng and Aster, 2004; Proweller et al., 2006).

Although several highly potent $\gamma$-secretase inhibitors are available, reports of significant toxicity associated with pharmacological inhibition of $\gamma$-secretase using these compounds (Milano et al., 2004; Wong et al., 2004; Barten et al., 2005) raised concerns regarding the value of $\gamma$-secretase for AD therapy. However, it is unclear whether toxicities associated with these $\gamma$-secretase inhibitors are attributable to mechanism-based side effects or are related to specific off-target side effects of these compounds. Moreover, high doses of these compounds were used in these studies to ensure strong inhibition of $\gamma$-secretase activity in vivo. Because complete inhibition of $\gamma$-secretase is predicted to be toxic, it is possible that modest inhibition of this enzyme may be sufficient to achieve the therapeutic benefit for $\mathrm{AD}$ without severe liabilities. However, it is not known whether there exists such a therapeutic window of modest inhibition of $\gamma$-secretase. To test the possibility that modest inhibition of $\gamma$-secretase can effectively attenuate $\mathrm{A} \beta$ amyloidosis but limit mechanism-based side effects, we assessed the phenotypic conse- 
quences of genetic reduction of $\gamma$-secretase activity using mice lacking one allele of PS1 (Wong et al., 1997), Nct (Li et al., 2003b), or Aph-1a (Ma et al., 2005) to generate a series of mice with different levels of $\gamma$-secretase activity. Our results established that modest reduction of $\gamma$-secretase allows the dissociation of beneficial effects achieved in the CNS from the mechanism-based toxicities associated with inhibition of $\gamma$-secretase.

\section{Materials and Methods}

Animals and cell lines. $\mathrm{Nct}^{+/-}, \mathrm{Aph}-1 \mathrm{a}^{+/-}, \mathrm{PS}^{+/-}$, and APPswe;PS1DE9 (line 57) mice were generated as described previously (Wong et al., 1997; Jankowsky et al., 2003; Li et al., 2003b; Ma et al., 2005). Nct ${ }^{+/-}$or Aph$1 a^{+/-}$mice were crossed with $A P P^{\text {swe }} ; P S 1 \triangle E 9$ mice to generate $A P P^{\text {swe }}$; $P S 1 \Delta E 9 ; \mathrm{Nct}^{+/+}, A P P^{\text {swe }} ; P S 1 \Delta E 9 ; \mathrm{Nct}^{+/-}, \mathrm{APP}^{\text {swe }} ; \mathrm{PS} 1 \Delta E 9 ; \mathrm{Aph}-1 \mathrm{a}^{+/+}$, and $A P P^{\text {swe }} ; P S 1 \triangle E 9 ; A p h-1 a^{+/-}$mice. The $\mathrm{Nct}^{+/-}$mice were maintained in a hybrid background of $129 \mathrm{sv}$ and C57BL/6/J. Mice for behavioral analysis were generated in C57BL/6/J congenic background by backcrossing B6/129 mice with C57BL/6/J mice for at least 10 generations. $\mathrm{Nct}^{+/-}$mice were crossed with $P S 1^{+/-}$mice to generate $\mathrm{Nct}^{+/-} ; \mathrm{PS1^{+/- }}$ mice, which were kept on a hybrid background of 129 sv and C57BL/6/J. All procedures involving mice were performed under the guidelines of the Johns Hopkins Medical Institutions Institutional Animal Care and Use Committee.

$\mathrm{Nct}^{+/-}, \mathrm{Nct}^{-/-}, \mathrm{Aph}-1 \mathrm{a}^{+/-}, \mathrm{Aph}-1 \mathrm{a}^{-/-}, \mathrm{PS}^{+/-}, \mathrm{PS1}^{-/-}$, and wildtype fibroblasts were generated as described previously (Li et al., 2003b; Ma et al., 2005). All cell lines were maintained in DMEM supplied with $10 \%$ of fetal bovine serum with antibiotic and L-glutamine (Invitrogen, Carlsbad, CA).

Immunoblot and antibodies. Immediately after the mice were killed, mouse tissues (brain and skin) were dissected, and proteins were extracted with T-PER Tissue Protection Extraction Reagent buffer (Pierce, Rockford, IL) containing complete protease inhibitor cocktail (Roche Diagnostics, Indianapolis, IN). The protein concentrations in the supernatants were determined by the BCA method (Pierce), and equal amount of protein lysates were resolved on 4-20\% Tris-glycine SDS-PAGE gels, transferred to polyvinylidene difluoride (Invitrogen, Carlsbad, CA) membranes, and probed with the following antibodies: anti-Nicastrin ( $\mathrm{Li}$ et al., 2003b) and antisera specific for PS1 (Thinakaran et al., 1996) (PS1-NTF, 1:5000; PS1-loop, 1:2500) and anti-PEN-2 (1:2000) (Luo et al., 2003). APP and APP-C-terminal fragments (CTFs) were detected by antibody CT-15 (Chemicon, Temecula, CA), and monoclonal antibody against actin and rabbit anti-tubulin antisera were purchased from Sigma (St. Louis, MO). Anti-Aph-1aL antibody was purchased from Covance (Princeton, NJ). Immunoblots were developed using the enhanced chemiluminescence method (Millipore, Bedford, MA).

In vitro $\gamma$-secretase activity assay. The $\gamma$-secretase activity of mouse brains were performed as described previously (Li et al., 2000). After mouse brain membranes were extracted in buffer A (in mM: 50 MES, pH $6.0,5 \mathrm{MgCl}_{2}, 5 \mathrm{CaCl}_{2}$, and $150 \mathrm{KCl}$ ) with $1 \times$ complete protease inhibitor mixture (Roche Diagnostics), and $8 \mu \mathrm{g}$ of membrane protein was incubated with APP recombinant substrate $(1 \mu \mathrm{M})$ in the presence of $0.25 \%$ 3-[(3-cholamidopropyl)dimethylammonio]-2-hydroxy-1-propanesulfonate in buffer B (in mM: 50 PIPES, pH 7.0, $5 \mathrm{MgCl}_{2}, 5 \mathrm{CaCl}_{2}$, and 150 $\mathrm{KCl})$ at $37^{\circ} \mathrm{C}$. The reactions were stopped by adding radioimmunoprecipitation buffer ( $150 \mathrm{~mm} \mathrm{NaCl}, 1.0 \% \mathrm{NP}-40,0.5 \%$ sodium deoxycholate, $0.1 \%$ SDS, and $50 \mathrm{~mm}$ Tris- $\mathrm{HCl}, \mathrm{pH}$ 8.0) and assayed with G2-10 antibody, which recognizes the $\mathrm{C}$ terminus of $\mathrm{A} \beta_{40}$ by ECL.

Filter trap assay. Cellulose acetate membranes with $0.2 \mu \mathrm{m}$ pore size (OE66; Whatman, Dassel, Germany) were used to trap the aggregates containing $\mathrm{A} \beta$ from the brain lysate (Xu et al., 2002). Briefly, mouse brains were weighed and then homogenized in 10 vol of PBS, pH 7.4, containing a protease inhibitor cocktail (Roche Diagnostics). Homogenates were centrifuged at $3000 \mathrm{rpm}$ for $5 \mathrm{~min}$ at $4^{\circ} \mathrm{C}$ in a microcentrifuge. The protein concentrations in the supernatants were determined by the BCA method (Pierce). Before filtering, the samples were diluted with PBS $(100-200 \mu \mathrm{l})$ and adjusted to a final concentration of $1 \%$ SDS. After filtering, using a 96-well dot-blot apparatus (Bio-Rad, Hercules, CA), the membranes were washed twice with $500 \mu \mathrm{l}$ of PBS, pH 7.4, per well.
Proteins trapped by the filter were detected by rabbit anti-A $\beta$ antiserum (Invitrogen, South San Francisco, CA) following conditions used for immunoblotting analysis. To quantify the levels of $\mathrm{A} \beta$ aggregations trapped on the filters, density of each dot on the filter was measured by NIH ImageJ software. The dot densities of brain extracts from mutant mice were compared with that of wild-type control mice.

$A \beta$ assay. To measure the $\mathrm{A} \beta$ levels in vivo, the brains of APPswe; $P S 1 \Delta E 9 ; \mathrm{Nct}^{+/-}$and APPswe;PS1 $\mathrm{E} 9 ; \mathrm{Nct}^{+/+}$mice were dissected on ice and homogenized in PBS buffer containing complete protease inhibitor cocktail. After the lysates were centrifuged at $100,000 \times g$ for $30 \mathrm{~min}$, the supernatants containing soluble $\mathrm{A} \beta$ peptides were collected for assay, and the pellets were homogenized in $70 \%$ formic acid solution. After storage on ice for $1 \mathrm{~h}$, the formic acid lysates were centrifuged at $100,000 \times g$ for $1 \mathrm{~h}$, and the supernatants were collected and neutralized by $1 \mathrm{M}$ Tris-base solution. The concentrations of $\mathrm{A} \beta_{40}$ peptides in PBSsoluble fractions and formic acid-soluble fraction were measured using a quantitative sandwich ELISA kit (Biosource International, Camarillo, CA) that specifically detects human $\mathrm{A} \beta_{40}$. The concentrations of total protein extracts were determined by the BCA method (Pierce).

To assay the APP processing in fibroblasts, fibroblasts were infected with $5 \times 10^{6}$ plaque-forming units of adenovirus expressing human $\mathrm{APP}^{\text {swe }}$ as described previously (Cai et al., 2001) for $24-48 \mathrm{~h}$. A $\beta_{40}$ levels from culture supernatants of cells were measured using a quantitative sandwich ELISA kit (Invitrogen, South San Francisco, CA) that specifically detects human $\mathrm{A} \beta$.

Histology and immunohistochemical analysis. After the animals were killed, the necropsy was performed as described previously (Brayton et al., 2001). The soft tissues were collected and fixed in 10\% Formalin solution for $24 \mathrm{~h}$. Heads and bones were fixed and decalcified in $23 \%$ formic acid. Trimmed tissues were embedded in paraffin, sectioned, and stained with hematoxylin and eosin for histological analyses (Brayton et al., 2001).

For histological and immunohistochemical analysis of $\mathrm{A} \beta$ amyloidosis, mice were perfused with $4 \%$ paraformaldehyde (PFA) in PBS. Brains were removed, embedded in paraffin, sectioned, and processed. Sections were analyzed immunohistochemically by the peroxidase-antiperoxidase method using antibodies specific for $\mathrm{A} \beta$ (4G8 and 6E10; Covance) and ubiquitin (Dako North America, Carpinteria, CA).

Measurement of amyloid plaques in mouse brain by stereology. To assess the $\mathrm{A} \beta$ plaque load, one-half of the sagittally bisected mouse brain was immersion fixed in $4 \%$ of PFA and embedded in paraffin. The brains were sectioned at $10 \mu \mathrm{m}$, and sections were selected at eight-section intervals for analysis using a light microscope interfaced with a Stereo Investigator (MicroBrightField, Williston, VT). The quantitative analysis was based on area fraction of ubiquitin immunoreactivity as described previously (Vehmas et al., 2001).

Water maze testing. Testing was conducted as described previously (Savonenko et al., 2005). Before the task, mice were pretrained to climb and stay on a submerged platform $(10 \times 10 \mathrm{~cm})$ placed in the center of a small pool ( $45 \mathrm{~cm}$ diameter). During the pretraining ( $2 \mathrm{~d}$ for five trials), a mouse was placed into the water (face to the platform) and allowed to swim, climb on the platform, and stay there for $10 \mathrm{~s}$. Then it was picked up by the tail, dried with a paper towel, and returned to a warm dry cage for 7-8 min (an average duration of intertrial interval). Thus, before starting the classic Morris water maze task, all mice were familiarized with the procedural aspects of the task. The Morris water maze task was conducted in a pool $(100 \mathrm{~cm}$ diameter) filled with opaque water $(22 \pm$ $2{ }^{\circ} \mathrm{C}$ ) and surrounded by a set of distal and proximal spatial cues. Four daily sessions included 10 platform trials, in which the platform was submerged but accessible to the mouse, as well as two probe trials (before and after the block of platform trials). During the probe trials, the platform was collapsed at the bottom of the tank for variable intervals $(30-40 \mathrm{~s})$. At the end of the probe trial, the collapsed platform was returned to its raised position, and the mouse was allowed to escape onto the platform. This probe trial protocol ensured the same responsereinforcement contingency as in the platform trials and allowed the use of probe trials repeatedly without the effect of extinction. If the mouse failed to locate the platform in $60 \mathrm{~s}$, the experimenter directed the mouse to the platform by hand, and the mouse remained on the platform for 

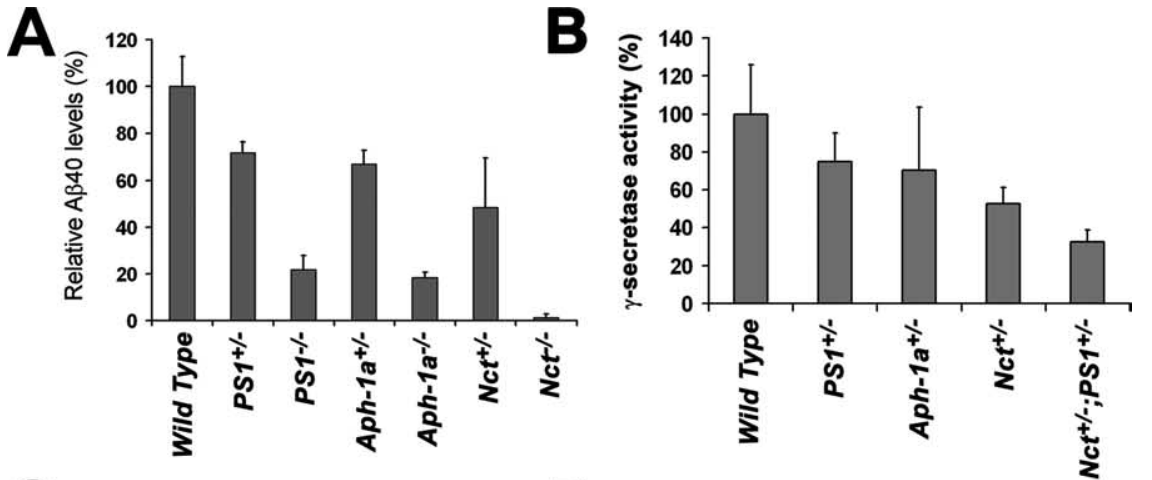

C Nct $+/++/++/-+/-+/++/++/-$ D APP;PS1 $\triangle E 9+++--$

Nct $+/++/-+/-+/++/++/-+/-$

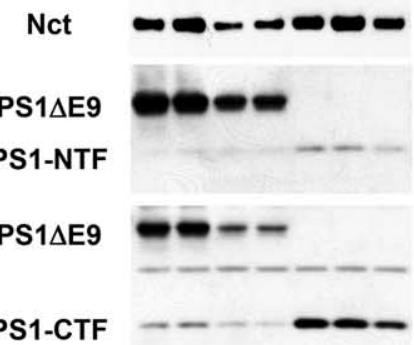

Actin

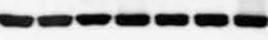

$\begin{array}{lllllll}1 & 2 & 3 & 4 & 5 & 6 & 7\end{array}$

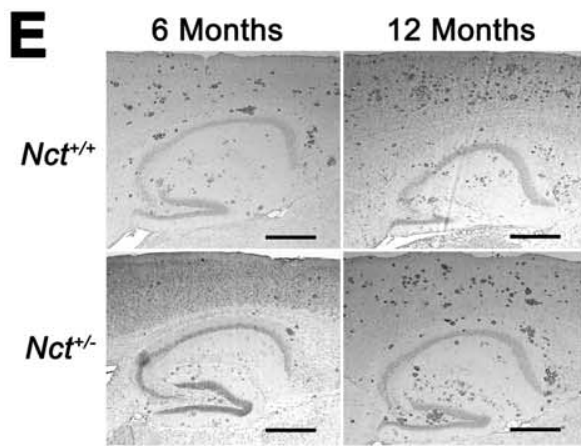

E

APP-FL

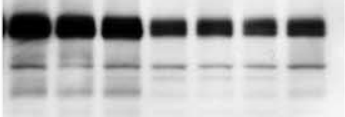

APP-CTFs

Actin
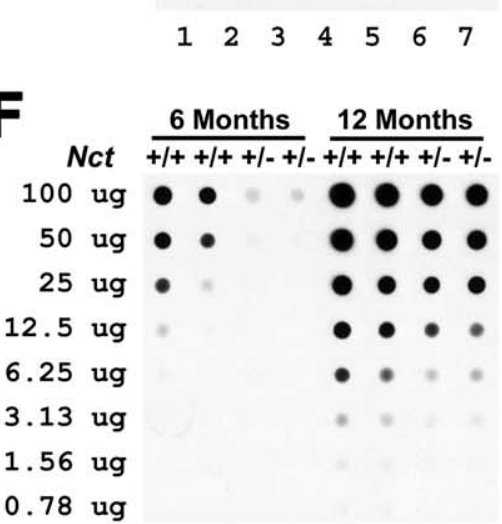

G

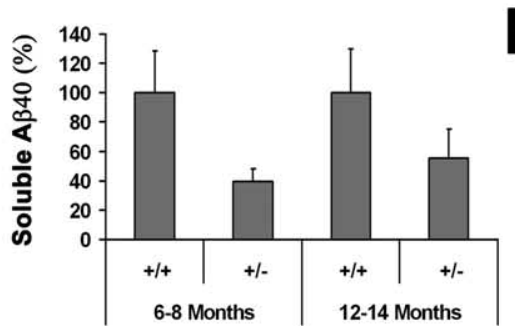

H

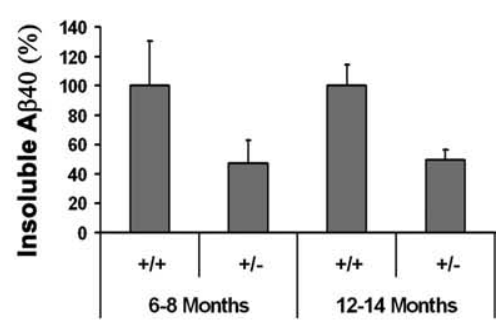

Figure 1. Reduction of $\gamma$-secretase activity attenuates $A \beta$ deposition in brains of $A P P S$ swe/PS1 $1 E 9 ; \mathrm{NCt}^{+/-}$mice. $A$, ELLSA analysis of secreted $A \beta_{40}$ peptides in the conditional medium of fibroblasts that have been infected with adenovirus-expressing $A P P^{\text {swe }}$ protein. The data were averages from four parallel experiments $(p=0.002)$. B, In vitro $\gamma$-secretase assay of brain extracts of wild-type, $\mathrm{PSI}^{+/-}, \mathrm{Aph} \mathrm{a}^{+/-}$, $\mathrm{NCt}^{+/-}$, and $\mathrm{NCt}^{+/-} ; \mathrm{PSI}^{+/-}$mice. The data were averages from four parallel experiments $(p=0.002)$. C, Protein extracts (40 $\mu$ geach) from

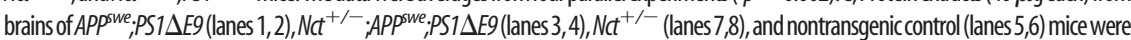
immunoblotted with antisera specificto Nct,PS1-NTF,PS1-CTF, oractin. D, Protein extracts (40 $\mu$ geach) frombrains of APp $P^{\text {swe, }}$,PS1 $\triangle E 9$ (lane 1), $\mathrm{NC}^{+/-}$;APPswe.PS1 $\mathrm{PEg}$ (lanes 2,3), $\mathrm{NC}^{+/-}$(lanes 6,7), and nontransgenic control (lanes 4,5) mice were immunoblotted with antisera that recognize full-length APP (APP-FL) and APP-CTFs. The same blotwas stripped and reblotted using antiserum specific to actin as loading control.

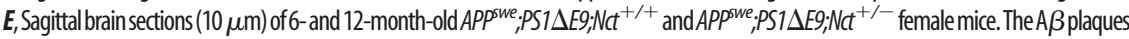
were visualized by immunostaining with antibodies specific to ubiquitin. Scale bars, $0.5 \mathrm{~mm} . F$, Quantitative analysis of the levels of $A \beta$ aggrega-

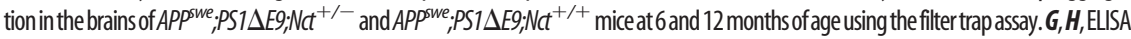
of soluble (PBS extraction, $G, n=6 ; p=0.05$ ) and insoluble (formic acid extraction, $H ; n=6 ; p=0.001$ ) $\mathrm{A} \beta_{40}$ peptides extracted from the

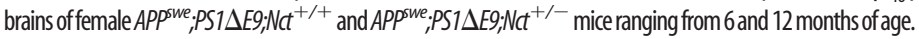

10 s. Distance (path from the start location to the platform, in centimeters) and swim speed (average speed during a trial, centimeters per second) were measured during the platform trials. In the probe trials, the measures recorded were swim speed, percentage of time spent in different quadrants, as well as the time spent in the area $40 \mathrm{~cm}$ in diameter around the location of platform (annulus 40).

Plus maze task. A plus maze task described previously (Andreasson et al., 2001) was used for testing anxiety in a young cohort of mice. For this test, the maze was raised $70 \mathrm{~cm}$ above the ground, and testing was performed in low diffuse lighting. Each subject was placed in the center of the apparatus and allowed to explore freely for $5 \mathrm{~min}$. An observer scored the number of arm entries made to the open and closed arms as well as time spent in each area.

Y-maze task. Testing was performed on a Y-shaped maze as described previously (Andreasson et al., 2001). Mice were placed into the end of one arm and allowed to explore freely for $5 \mathrm{~min}$. All arm entries are sequentially scored so that the total number of arm entries as well as the sequence of entries are recorded. The spontaneous alternation behavior was calculated as the number of triads containing entries into all three arms divided by the maximum possible alternations.

Flow cytometry. For flow cytometry analysis, splenocytes were prepared from spleens of $\mathrm{Nct}^{+/-}$and $\mathrm{Nct} t^{+/+}$littermate controls. After lysis of red blood cells with ACK lysis buffer (catalog number P304-100; Biosource International, Rockville, MD), the cells were washed in fluorescence-activated cell sorting (FACS) buffer (PBS and $0.5 \%$ bovine serum albumin) and incubated with specific antibody directly conjugated to fluorescein isothiocyanate or phycoerythrin, washed, and analyzed using a FACSCalibur and CELLQuest software (BD, Mountain View, CA). Monoclonal antibodies used were anti-CD3 (clone 17A2), anti-CD4 (clone GK1.5), anti-CD8 (clone 53-6.7), anti-CD19 (clone 1D3), antiNK1.1 (clone PK136), and anti-Ly-6G and Ly-6C (Gr-1, clone RB6-8C5). All the above monoclonal antibodies and antibody isotype controls were purchased from BD Biosciences PharMingen (San Diego, CA).

Data analysis. All data were analyzed statistically by Student's $t$ test or ANOVA. In all tests, the level of significance was at $p<0.05$.

\section{Results}

Mouse models with different levels of $\gamma$-secretase

Genetically engineered mice with reduced levels of $\gamma$-secretase provide useful animal models to validate $\gamma$-secretase as target for $\mathrm{AD}$ therapy. In our previous studies, we generated mice lacking different components of $\gamma$-secretase (Nct, PS1, and Aph-1a). $\gamma$-Secretase activity in fibroblasts derived from $\mathrm{Nct}^{+/-}, \mathrm{Aph}-1 \mathrm{a}^{+/-}$, and $\mathrm{PS1}^{+/-}$embryos are reduced to $\sim 50-70 \%$ of that of wild-type cells (Fig. 1A) (Li et al., 2003b; Ma et al., 2005). In contrast to our previous finding ( $\mathrm{Li}$ et al., 2003b), one study showed 
that secretion of $\mathrm{A} \beta$ peptides in $\mathrm{Nct}^{+/-}$fibroblasts was relatively higher than that of wild-type cells ( $\mathrm{Li}$ et al., 2003a). To clarify whether deleting one allele of Nct lead to reduction of $\gamma$-secretase in vivo, we first assess the levels of components of $\gamma$-secretase in brains of $\mathrm{Nct}^{+/+}$and $\mathrm{Nct}^{+/-}$mice. Nct and N-terminal fragments (NTFs) and C-terminal fragments of PS1 in brains of $\mathrm{Nct}^{+/-}$ mice were reduced compared with age-matched wild-type controls (Fig. 1C, lanes 5-7). In addition, whereas the level of endogenous full-length APP in brain was comparable between $\mathrm{Nct}^{+/+}$ and $\mathrm{Nct}^{+/-}$mice, the levels of APP-CTFs, direct substrates of $\gamma$-secretase, were increased in $\mathrm{Nct}^{+/-}$mice compared with that of $\mathrm{Nct}^{+/+}$mice (Fig. 1D, lanes $4-7$ ). These results indicate that the $\gamma$-secretase activity in brains of $\mathrm{Nct}^{+/-}$mice is reduced as compared with that of wild-type mice.

Because different components of $\gamma$-secretase may have different effects on $\gamma$-secretase, we assess $\gamma$-secretase activities in brains of mice lacking one alleles of PS1, Aph-1a, or Nct as well as mice lacking one allele each of Nct and PS1 using in vitro $\gamma$-secretase activity assay. The $\gamma$-secretase activity in brain extracts of $P S 1^{+/-}$, Aph $1 a^{+/-}, \mathrm{Nct}^{+/-}$, and $\mathrm{Nct}{ }^{+/-} ; P S 1^{+/-}$mice is reduced $\sim 25,30$, 50 , and $64 \%$, respectively, compared with that of wild-type mice (Fig. $1 B$ ). These results are consistent with our $\gamma$-secretase activity analysis of $\mathrm{PS1}^{+/-}, \mathrm{Aph1a^{+/- }}, \mathrm{Nct}^{+/-}$, and $\mathrm{Nct}^{+/-} ; \mathrm{PS1}^{+/-}$ fibroblasts (Fig. $1 A$ ), validating that these mice are useful animal models to evaluate the effects and consequences of chronic reduction of $\gamma$-secretase activity to different levels.

\section{Reduction of Nct attenuates $\mathrm{A} \boldsymbol{\beta}$ generation and deposition in APPswe;PS1DE9 mice}

To examine whether $\mathrm{A} \beta$ deposition is sensitive to the dosage of $\gamma$-secretase in the CNS, we crossbred $\mathrm{Nct}^{+/-}$mice with $A P P^{\text {swe }}$; $P S 1 \triangle E 9$ mice, a well established model exhibiting accelerated A $\beta$ amyloidosis attributable to coexpression of familial AD linked mutations of APP $\left(A P P^{\text {swe }}\right)$ and PS1 $(P S 1 \triangle E 9)$ in CNS of mice (Jankowsky et al., 2003), to generate $A P P^{\text {swe }} ; P S 1 \Delta E 9 ; N c t^{+/-}$and $A P P^{\text {swe }} ; P S 1 \triangle E 9 ; \mathrm{Nct}^{+/+}$animals. As we observed in $\mathrm{Nct}^{+/-}$mice, levels of Nct, PS1 $\Delta \mathrm{E} 9$, and endogenous PS1 NTFs and PS1 CTFs in $A P P^{\text {swe }} ; P S 1 \triangle E 9 ; N_{c t}{ }^{+/-}$mice were decreased compared with that of $A P P^{\text {swe }} ; P S 1 \triangle E 9 ; N_{c t}{ }^{+/+}$mice (Fig. $1 C$, lanes 1-4), indicating that a decrease in the level of Nct is sufficient to reduce $\gamma$-secretase complexes in $A P P^{\text {swe }} ; P S 1 \triangle E 9$ mice.

To assess the impact of genetic reduction of $\gamma$-secretase on the $\mathrm{A} \beta$ burden, we used several complementary methods. First, immunohistochemical analysis using antibodies against ubiquitin (or against $\mathrm{A} \beta$; data not shown) revealed that $\mathrm{A} \beta$ deposition in $A P P^{\text {swe }} ; P S 1 \triangle E 9 ; \mathrm{Nct}^{+/-}$mice was dramatically reduced compared with that of $A P P^{\text {swe }} ; P S 1 \triangle E 9 ; N_{c t} t^{+/+}$mice at 6 or 12 months of age (Fig. $1 E$ ). Unbiased stereology analysis showed a $48.8 \%$ $(n=5 ; p=0.027)$ reduction of $\mathrm{A} \beta$ burden in cortex and hippocampus area in $A P P^{\text {swe }} ; P S 1 \triangle E 9 ; N c t^{+/-}$mice when compared with that of $A P P^{\text {swe }} ; P S 1 \Delta E 9 ; N_{c t} t^{+/+}$mice at 12 months of age. Quantitative analysis in brains of the same set of mice using the filter trap assay confirmed reduction of $\mathrm{A} \beta$ deposits in $A P P^{\text {swe }}$; $P S 1 \Delta E 9 ; N_{c t}{ }^{+/-}$mice $\left(47.1 \pm 21 \%\right.$ of $A P P^{s w e} ; P S 1 \Delta E 9 ; N_{c t}{ }^{+/+}$ mice, $n=3$ ) (Fig. $1 F$ ). Moreover, the levels of soluble and insoluble $A \beta$ peptides extracted by formic acid from the brains of the same set of mice was significantly lower in $A P P^{\text {swe }} ; P S 1 \triangle E 9$; $\mathrm{Nct}^{+/-}$compared with APP ${ }^{\text {swe }} ; P S 1 \Delta E 9 ; \mathrm{Nct}^{+/+}$mice (Fig. 1G,H). These results are consistent with the concept that $\sim 50 \%$ reduction of $\gamma$-secretase activity by deleting one allele of Nct can efficiently reduce the generation of $\mathrm{A} \beta$ peptides and ameliorate $\mathrm{A} \beta$ amyloidosis in the CNS.

\section{Reduction of Aph-1a attenuates $\mathrm{A} \beta$ generation and deposition in APPswe;PS1 $\triangle E 9$ mice}

Having established that $\mathrm{A} \beta$ deposition is sensitive to the dosage of $\gamma$-secretase, we predict that modest inhibition of $\gamma$-secretase to $<50 \%$ should ameliorate $\mathrm{A} \beta$ amyloidosis in the brain. Because $\gamma$-secretase activity in brain of $A p h-1 a^{+/-}$mice showed a $\sim 30 \%$ reduction compared with that of wild-type mice (Fig. $1 B$ ), we elected to test this prediction by crossbreeding these $A p h-1 a^{+/-}$ mice with $A P P^{\text {swe }} ; P S 1 \triangle E 9$ mice to generate $A P P^{\text {swe }} ; P S 1 \triangle E 9 ; A p h$ $1 a^{+/-}$and $A P P^{\text {swe }} ; P S 1 \Delta E 9 ; A p h-1 a^{+/+}$animals. Protein levels of Nct, PS1 $\Delta$ E9, and Aph-1a in APP ${ }^{\text {swe }} ; P S 1 \Delta E 9 ; A p h-1 a^{+/-}$mice were decreased compared with that of $A P P^{\text {swe }} ; P S 1 \triangle E 9 ; A p h-$ $1 a^{+/+}$mice (Fig. $2 A$ ). Immunohistochemical analysis using antibodies against ubiquitin revealed that $\mathrm{A} \beta$ deposition in $A P P^{\text {swe }}$; $P S 1 \triangle E 9 ; A p h-1 a^{+/-}$mice was reduced compared with that of $A P P^{\text {swe }} ; P S 1 \Delta E 9 ; A p h-1 a^{+/+}$mice at both 6 and 12 months of age (Fig. 2 B). Unbiased stereology analysis showed a $35 \%$ reduction of $\mathrm{A} \beta$ burden in $A P P^{\text {swe }} ; P S 1 \triangle E 9 ; A p h-1 a^{+/-}$compared with that of $A P P^{\text {swe }} ; P S 1 \triangle E 9 ; A p h-1 a^{+/+}$mice at 12 months of age $(n=5$; $p=0.05)$. Quantitative analysis using the filter trap assay confirmed that there was $35 \pm 16 \%(n=3)$ reduction of $\mathrm{A} \beta$ deposits in $A P P^{\text {swe }} ; P S 1 \triangle E 9 ; A p h-1 a^{+/-}$compared with that of $A P P^{\text {swe }}$; $P S 1 \triangle E 9 ; A p h-1 a^{+/+}$mice at 12 months of age (Fig. $2 C$ ). As expected, the levels of both soluble and insoluble $A \beta_{40}$ peptide extracted from the brains of the same set of mice were lower in $A P P^{\text {swe }} ; P S 1 \triangle E 9 ; A p h-1 a^{+/-}$compared with that of $A P P^{\text {swe }}$; $P S 1 \Delta E 9 ; A$ ph $-1 a^{+/+}$mice (Fig. $2 D$ ). Together, using two independent mouse models, we demonstrate that modest decrement of $\gamma$-secretase activity to $30-50 \%$ is sufficient to attenuate $\mathrm{A} \beta$ burden in the CNS. Moreover, the correlation between the amounts of $\mathrm{A} \beta$ deposition and the levels of $\gamma$-secretase suggests that this enzyme functions stoichiometrically in processing of APP derivatives in the brain, supporting the notion that $\gamma$-secretase is a potential therapeutic target for attenuation of $\mathrm{A} \beta$ burden.

\section{The risk of developing skin tumors is dependent on the levels of $\boldsymbol{\gamma}$-secretase in mice}

Because the value of $\gamma$-secretase as a useful therapeutic target depends on whether chronic inhibition of $\gamma$-secretase is associated with severe mechanism-based side effects, we assessed the consequences of chronic reduction of $\gamma$-secretase to different levels in a series of mice with genetic reduction of various components of $\gamma$-secretase complex. Deletions of one or both alleles of Nct, PS1, or Aph-1a led to reduction of $\gamma$-secretase activity to different levels in mouse brains and in fibroblasts derived from embryos of these mutant mice (Fig. $1 A, B$ ). In skin extracts derived from $\mathrm{Nct}^{+/-}$mice, levels of $\gamma$-secretase components, NCT, PS1-NTF, PS1-CTF, and PEN-2, were reduced $\sim 50 \%$, findings that are consistent with the view that $\gamma$-secretase is reduced globally in $\mathrm{Nct}^{+/-}$mice (Fig. 3A). In addition, by crossbreeding $\mathrm{PS}^{+/-}$mice with $\mathrm{Nct}^{+/-}$mice, we generated $\mathrm{Nct}^{+/-} ; \mathrm{PS} 1^{+/-}$ mice with additional reduction of $\gamma$-secretase compared with $\mathrm{Nct}^{+/-}$mice. As expected, the levels of Nct, PS1 fragments, and Pen-2 in skin of $\mathrm{Nct}^{+/-} ; \mathrm{PS1}^{+/-}$mice were decreased compared with that of $\mathrm{Nct}^{+/-}$mice (Fig. $3 B$ ). Therefore, we generated a series of mice with different levels of $\gamma$-secretase, allowing us an opportunity to study the consequences of chronic reduction of $\gamma$-secretase ranging from $\sim 25$ to $64 \%$ of wild-type level.

Previous studies indicated that deficiency in PS1 increased the risk of tumorigenesis in the skin (Xia et al., 2001). Consistent with the view that $\gamma$-secretase can serve as a tumor suppressor in epithelium, we found that $\mathrm{Nct}^{+/-}$mice start to develop skin lesions 

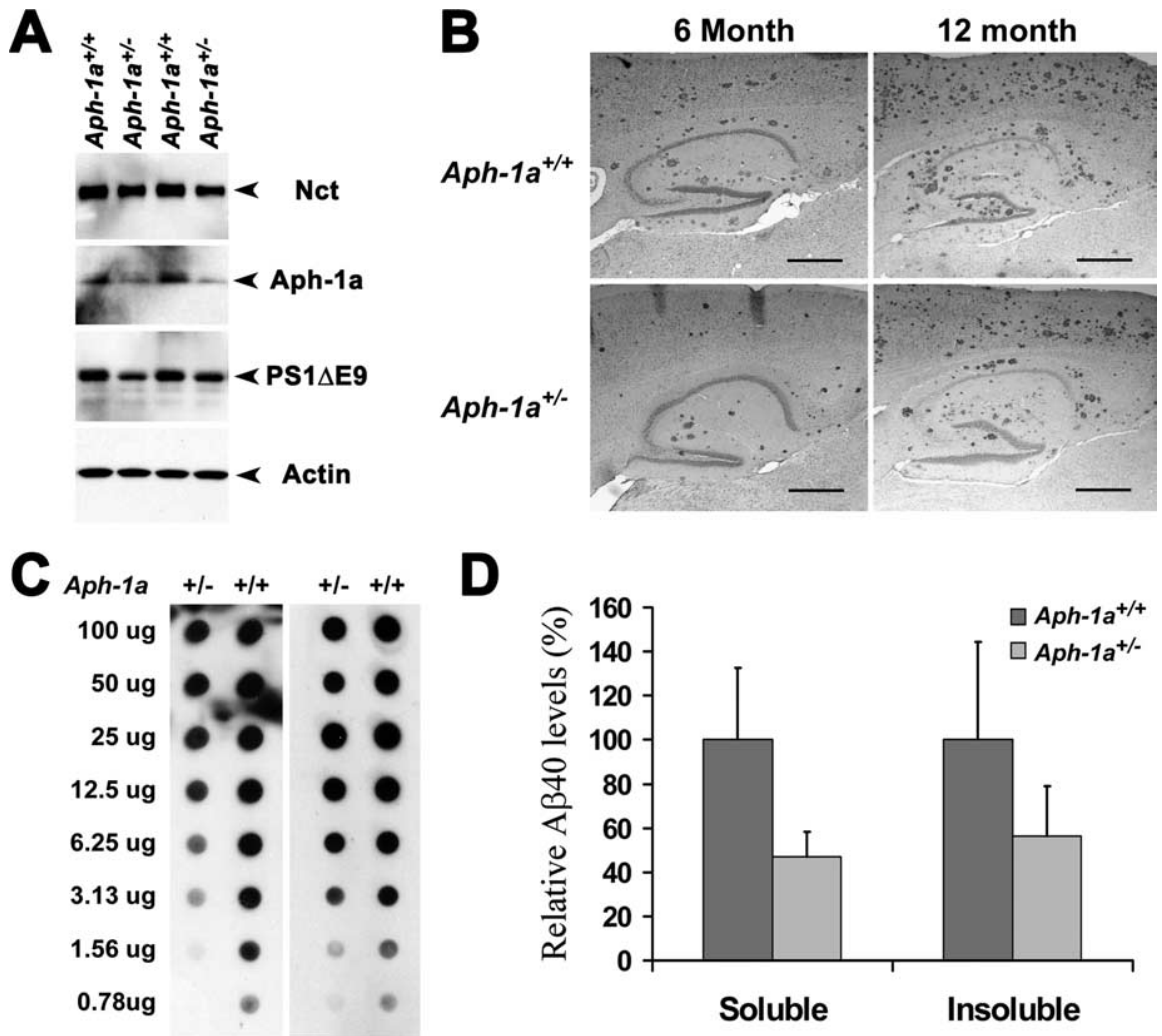

Figure 2. Reduction of $\gamma$-secretase activity attenuates $A \beta$ deposition in brains of APPswe/PS1 $\triangle E 9 ; A p h-1 a^{+/-}$mice. $\boldsymbol{A}$, Protein extracts (40 $\mu \mathrm{g}$ each) from brains of $A P P^{5 \text { swe }} ; P S 1 \triangle E$ E; $A$ Ph- $1 a^{+/+}$and $A P P^{\text {swe }} ; P S 1 \triangle E 9 ; A p h-1 a^{+/-}$were immunoblotted with antisera specific to Nct, Aph-1aL, PS1-NTF, and actin. B, Sagittal brain sections (10 $\mu \mathrm{m})$ of 6- and 12-month-old APpswe,

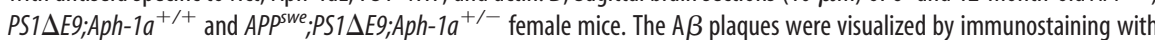
antibodies specific to ubiquitin. Scale bars, $0.5 \mathrm{~mm}$. C, Filter trap analysis of $A \beta$ aggregation in the brains of APPswe; $P S 1 \triangle E$; ; $\mathrm{Nct}^{+/-}$and $A P P^{\text {swe }}, \mathrm{PS} 1 \Delta E 9 ; \mathrm{NCt}^{+/+}$mice at 12 months of age. $\boldsymbol{D}$, ELISA of insoluble (formic acid extraction) and soluble (PBS extraction) $A \beta_{40}$ peptides extracted from the brains of female $A P P^{5 \text { wwe }} ; P S 1 \Delta E 9 ; A p h-1 a^{+/+}$and $A P P^{5 \text { wwe }} ; P S 1 \Delta E 9 ; A p h-1 a^{+/-}$ mice at 12 months of age $(n=5 ; p=0.034)$.

at approximately 25 weeks of age. The initial skin lesions in $\mathrm{Nct}^{+\prime-}$ mice were usually at the face and around the tail (supplemental Fig. $1 A, B$, available at www.jneurosci.org as supplemental material). Most of the $\mathrm{Nct}^{+/-}$mice also develop squamous metaplasia and proliferative changes in sebaceous glands, including Zymbal, Meibomian, preputial, and clitoral gland (supplemental Fig. $1 C, D$, available at www.jneurosci.org as supplemental material). Lesions progressed to invasive squamous cell carcinoma (SCC) in $\sim 50 \%$ of the $\mathrm{Nct}^{+/-}$mice (Fig. $3 \mathrm{E}$, F; Table 1). Most $\mathrm{Nct}^{+/-}$mice developed multiple proliferative skin lesions; sometimes multiple invasive tumors formed in older $\mathrm{Nct}^{+--}$mice. Importantly, in one highly invasive case of head and neck SCC among the 14 cases examined, metastatic foci were detected in renal cortex (Fig. $3 G$ ), further supporting the malignant character of these tumors. The median age at which tumors appear in $\mathrm{Nct}^{+/-}$mice $(n=89)$ is $\sim 60$ weeks (vs $>125$ weeks in wild-type mice; $n>100$ ) (Fig. $3 C$ ). Among $\mathrm{Nct}^{+/-}$mice that were at least 100 weeks old $(n>30),>90 \%$ developed skin tumors. Although a small percentage of wild-type control mice developed various tumors at older age (between 90 and 125 weeks; $n>50$ ), they rarely developed skin lesions even at $>2$ years of age (Table 1). Moreover, $\mathrm{Nct}^{+/-}$mice died with a median lifespan of 94 weeks, which was much shorter than wild-type mice ( $\sim 135$ weeks) (Fig. 3D). The shorter lifespan of $\mathrm{Nct}^{+/-}$mice was attributed at least in part to their increased tumor burden.

Interestingly, the risk of developing skin tumor is significantly increased in $\mathrm{Nct}^{+/-} ; \mathrm{PS1}^{+/-}$mice. Skin lesions similar to those found in older $\mathrm{Nct}^{+/-}$mice developed as early as 1 month of age in $\mathrm{Nct}^{+/-} ; \mathrm{PS1}^{+/-}$mice and were observed in $>90 \%$ of $\mathrm{Nct}^{+/-} ; \mathrm{PS1}^{+/-}$mice older than 12 months of age. The median age of tumor development in $\mathrm{Nct}^{+/-}$; $P S 1^{+/-}$mice (45 weeks; $n=45$ ) is accelerated when compared with $\mathrm{Nct}^{+/-}$mice (60 weeks; $n=89$ ) (Fig. 3C). Moreover, $\mathrm{Nct}^{+/-} ; \mathrm{PS1}^{+/-}$mice died with a median lifespan of 71 weeks, which was significantly shorter than that of $\mathrm{Nct}^{+/-}$mice $(94$ weeks) or wild-type mice $(\sim 135$ weeks $)$ (Fig. 3D). More importantly, histological analysis revealed that skin lesions in $\mathrm{Nct}^{+/-} ; \mathrm{PSI}^{+/-}$mice (Fig. $3 \mathrm{H}$ ) were similar to those observed in $\mathrm{Nct}^{+/-}$mice (Fig. $3 E, F)$, with early lesions consisting of follicular and epidermal inclusion cysts, and with areas of dysplasia and atypical basal cell proliferation. However, lesions found in $\mathrm{Nct}^{+/-} ; \mathrm{PS1}^{+/-}$mice appeared earlier and progressed to invasive squamous cell carcinoma at a higher rate compared with that in $\mathrm{Nct}^{+/-}$mice, indicating that the risk of skin tumor in mice is dependent on the level of $\gamma$-secretase.

$\mathrm{Nct}^{+/-}$and $\mathrm{Nct}^{+/-} ; \mathrm{PS1}^{+/-}$mice also showed proliferative lesions in other tissues, including forestomach (supplemental Fig. $1 F$, available at www.jneurosci.org as supplemental material). In forestomach, $>70 \%$ of $\mathrm{Nct}^{+/-}$mice $(n=29)$ developed squamous mucosal hyperplasia, and some mice showed atypical basal cell proliferation and other dysplastic changes (supplemental Fig. $1 F$, available at www.jneurosci.org as supplemental material). Forestomach lesions were relatively rare in wild-type mice, and the common occurrence of dysplasia at this site in $\mathrm{Nct}^{+/-}$mice and $\mathrm{Nct}^{+/-} ; \mathrm{PS1}^{+/-}$mice suggests that $\gamma$-secretase is required to suppress proliferation of this type of epithelia as well. Interestingly, other than SCC, tumor development in $\mathrm{Nct}^{+/-}$and $\mathrm{Nct}^{+/-} ; \mathrm{PS1}^{+/-}$mice was not significantly different compared with wild-type mice (Table 1), indicating that $\gamma$-secretase is a specific tumor suppressor in epithelium.

To further assess the relationship between the level of $\gamma$-secretase and the risk of tumorigenesis in mice, we analyze two lines of mice that maintain higher levels of $\gamma$-secretase than that of $\mathrm{Nct}^{+/-}$mice. $\mathrm{PS1}^{+/-}$and Aph-1 $a^{+/-}$mice harbor 75 and $70 \%$, respectively, of $\gamma$-secretase compared with wild-type mice. Interestingly, $\mathrm{PSI}^{+/-}$and $\mathrm{Aph}-1 \mathrm{a}^{+/-}$mice failed to develop any skin cancers as observed in $\mathrm{Nct}^{+/-}$mice. Although they developed various tumors at older age, the tumor type and risk of tumorigenesis observed in $\mathrm{PSI}^{+/-}$and $\mathrm{Aph}-1 \mathrm{a}^{+/-}$mice were similar to that of wild-type mice (Fig. 3C). The life expectancies of these two mutant lines were also similar to that of control littermates (Fig. $3 D$ ). In addition, squamous cell hyperproliferation is rarely observed in $\mathrm{PSI}^{+/-}$and $\mathrm{Aph}-1 \mathrm{a}^{+/-}$mice, even in some mice that have developed other types of tumors, such as sarcoma that has invaded into the skin. These data indicate that a critical $\gamma$-secretase level is required to protect epithelia from tumorigenesis; whereas inhibition of $\gamma$-secretase up to $30 \%$ in mice does not 


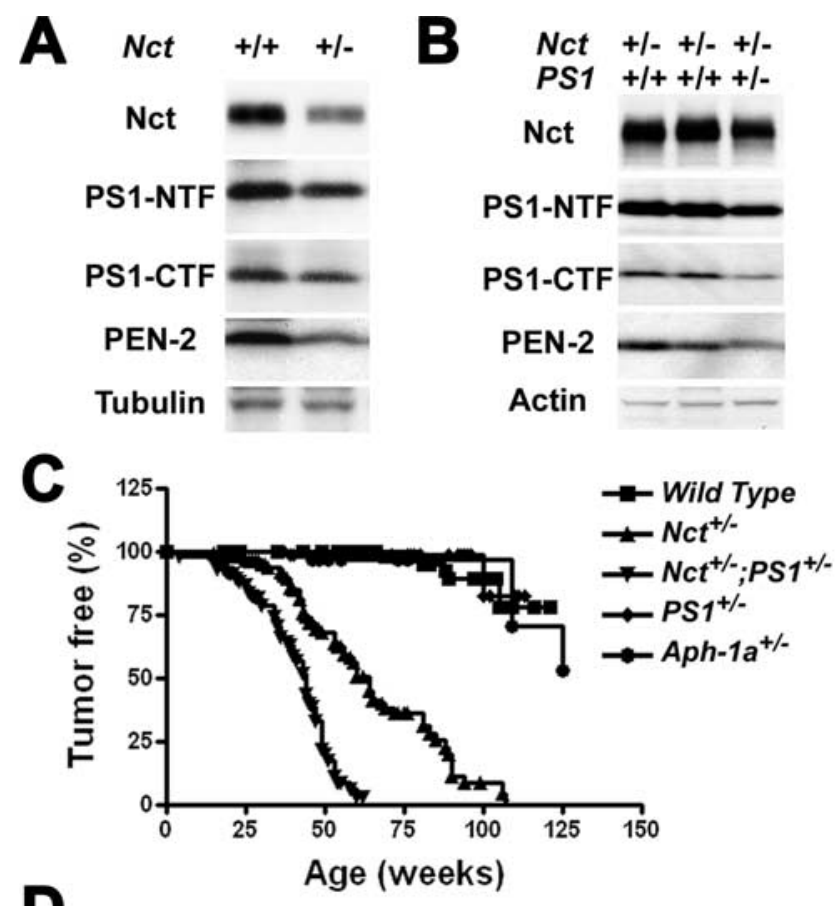

D
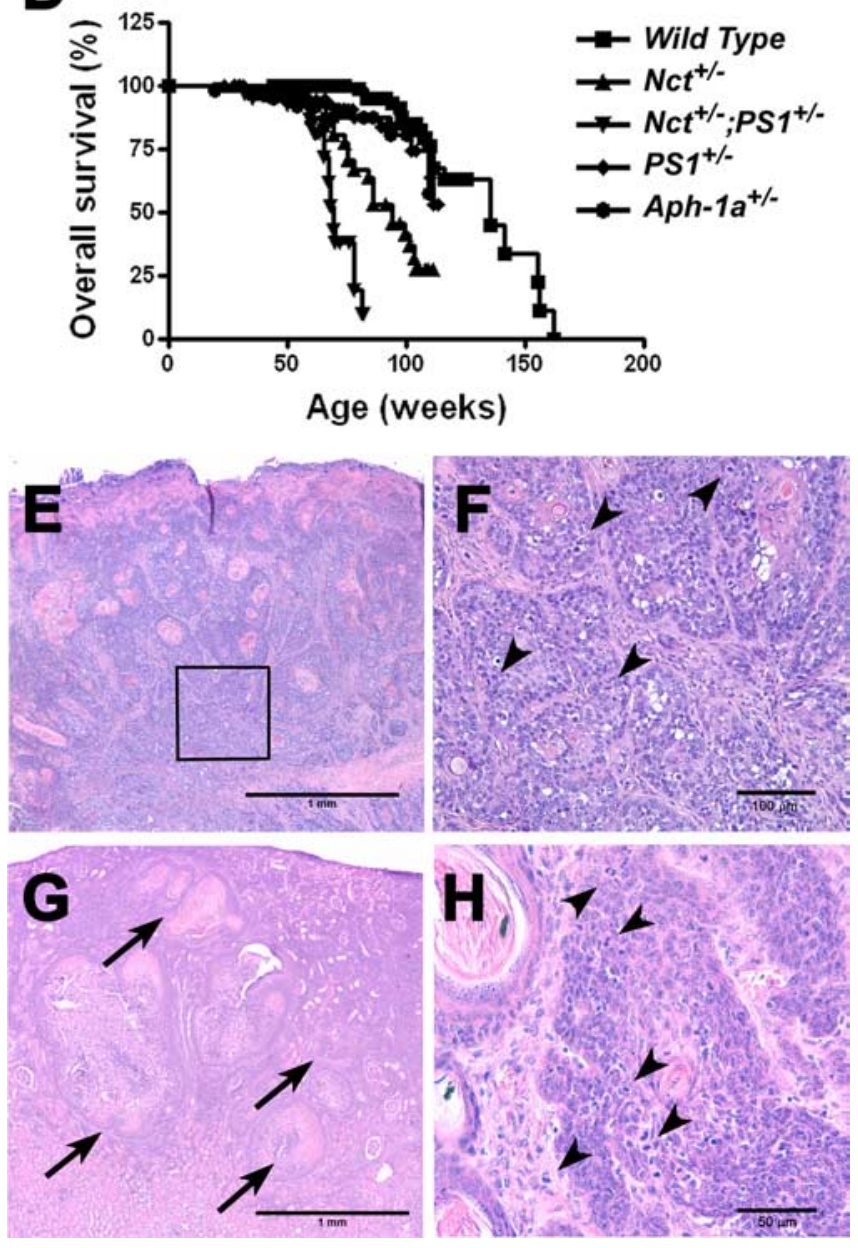

Figure 3. Mice with reduced $\gamma$-secretase activity develop spontaneous tumors. $\boldsymbol{A}$, Protein extracts (40 $\mu \mathrm{g}$ each) from skin of $\mathrm{Nct}^{+/+}$and $\mathrm{Nct}^{+/-}$mice were immunoblotted with antisera specific to Nct, PS1-NTF, PS1-CTF, or PEN-2. Immunoblots were striped and reprobed using antiserum against $\beta$-tubulin as loading control. B, Protein extracts (40 $\mu \mathrm{g}$ each) from skins of $\mathrm{Nct}^{+/-}$and $\mathrm{Nct}^{+/-} ; \mathrm{PS}^{+/-}$mice were immunoblotted with antisera specific to $\mathrm{Nct}$, PS1-NTF, PS1-CTF, or PEN-2. Immunoblots were striped and reprobed using antiserum against
Table 1. Histological diagnosis of wild-type and $\mathrm{Nct}^{+/-}$mice

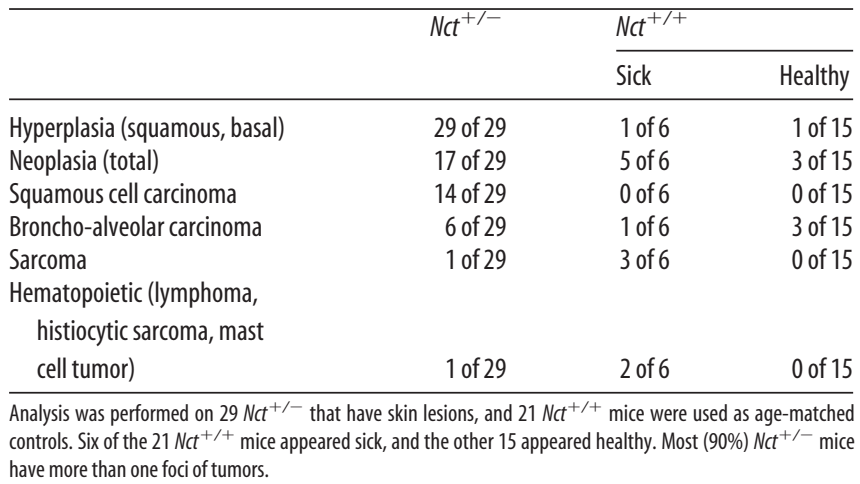

increase the risk of SCC, $\geq 50 \%$ reduction of $\gamma$-secretase leads to a significant increase in the risk of tumorigenesis.

Enlargement of spleen in mice with reduced $\gamma$-secretase It has been reported that treatment of mice with $\gamma$-secretase inhibitors lead to mechanism-based toxicity of gastrointestinal abnormalities, gradually suppressed CD8 positive $T$ cells, increased appearance of immature B cells in the blood (Wong et al., 2004), and lymphoid depletion in the marginal zone of the spleen (Milano et al., 2004). However, we did not observe any of these abnormalities in our mice with genetic reduction of $\gamma$-secretase activity to different levels. In contrast, $\mathrm{Nct}^{+/-}$and $\mathrm{Nct}^{+/-} ; \mathrm{PSI}^{+/-}$ mice developed splenomegaly as observed in $\mathrm{PS1}^{+/-} ; \mathrm{PS}^{-/-}$ mice (Qyang et al., 2004). The average size of spleens in $\mathrm{Nct}^{+/-}$ and $\mathrm{Nct}^{+/-} ; \mathrm{PS1}^{+/-}$mice were approximately threefold larger than that of wild-type control mice (Fig. 4A,D), whereas sizes of other organs of $\mathrm{Nct}^{+/-}$and $\mathrm{Nct}^{+/-} ; \mathrm{PS1}^{+/-}$mice were not altered (Fig. 4A). The spleens of some $\mathrm{Nct}^{+/-}$and $\mathrm{Nct}^{+/-} ; \mathrm{PS1}^{+/-}$mice were in excess of $2 \mathrm{~g}$ (Fig. 4C). Histological analysis of enlarged spleens typically revealed marked expansion of red pulp by myelopoiesis (Fig. $4 F$ ) compared with that of wild-type mice (Fig. $4 E$ ). Newly formed granulocytes were particularly prominent in the spleen, paralleling with increased granulopoiesis in bone marrow in $\mathrm{Nct}^{+/-}$mice (Fig. $4 \mathrm{H}$ ) compared with that of wildtype mice (Fig. $4 G$ ), and neutrophilic leukocytosis in the peripheral blood as documented by both automated and manual cell counts (Fig. 4B). Flow cytometric analysis of spleen cell suspen-

actin as loading control. C, Kaplan-Meyer plots of tumor development in $\mathrm{Nct}^{+/+}, \mathrm{Nct}^{+/-}$, and $\mathrm{Nct}^{+/-} ; \mathrm{PS}^{+/-}$mice. Kaplan-Meyer plots of tumor development in $\mathrm{Nct}^{+/+}(n=96)$ and $\mathrm{Nct}^{+/-}(n=89)$ mice. Note that $\mathrm{Nct}^{+/-}$mice developed tumors with median age of $\sim 60$ weeks, and $>90 \%$ of $\mathrm{Nct}^{+/-}$mice developed skin tumors by 100 weeks of age; none of $\mathrm{Nct}^{+/+}$mice developed skin tumors by this age. The median age of tumor development in $\mathrm{Nct}^{+/-} ; \mathrm{PSI}^{+/-}$mice is greatly accelerated when compared with $\mathrm{Nct}^{+/-}$mice $(45 \mathrm{vs} 60$ weeks), and $>90 \%$ of $\mathrm{Nct}^{+/-} ; \mathrm{PS} 1^{+/-}$mice developed skin tumors by 60 weeks of age ( $p<$ 0.0001). D, Kaplan-Meyer survival plots for $\mathrm{Nct}^{+/+}, \mathrm{Nct}^{+/-}$, and $\mathrm{Nct}^{+/-} ; \mathrm{PS}^{+/-}$mice. Compared with wild-type mice, $\mathrm{Nct}^{+/-}$mice have a significantly shorter lifespan, with a median life expectancy of 94 weeks, whereas $\mathrm{NCt}^{+/-} ; \mathrm{PS} 1^{+/-}$mice have a further shortened lifespan, with median life expectancy of 71 weeks $(p<0.0001)$. Death is defined as the time when mice became moribund. $\boldsymbol{E}, \mathrm{SCC}$ near the tail of $\mathrm{Nct}^{+/-}$mice (33 weeks of age) shows moderately well differentiated invasive clusters of squamous type epithelial cells $(4 \times) . \boldsymbol{F}$, Higher magnification $(20 \times)$ of $\boldsymbol{E}$ (boxed area) showing moderately well differentiated invasive clusters of squamous type epithelial cells with cornification, disorganization, atypia, and mitotic figures (arrowheads). G, Squamous cell carcinoma (arrows) metastasized to the renal cortex in an $\mathrm{Nct}^{+/-}$mouse (98 weeks of age) $(4 \times)$. $\boldsymbol{H}$, Higher magnification $(40 \times)$ of skin lesions in $\mathrm{Nct}^{+/-} ; \mathrm{PS1^{+/- }}$ mice (21 weeks of ages) showing clusters of squamous epithelial cells with disorganization, atypia, and mitotic figures (arrowheads). All sections (10 $\mu \mathrm{m})$ were stained with hematoxylin and eosin. 

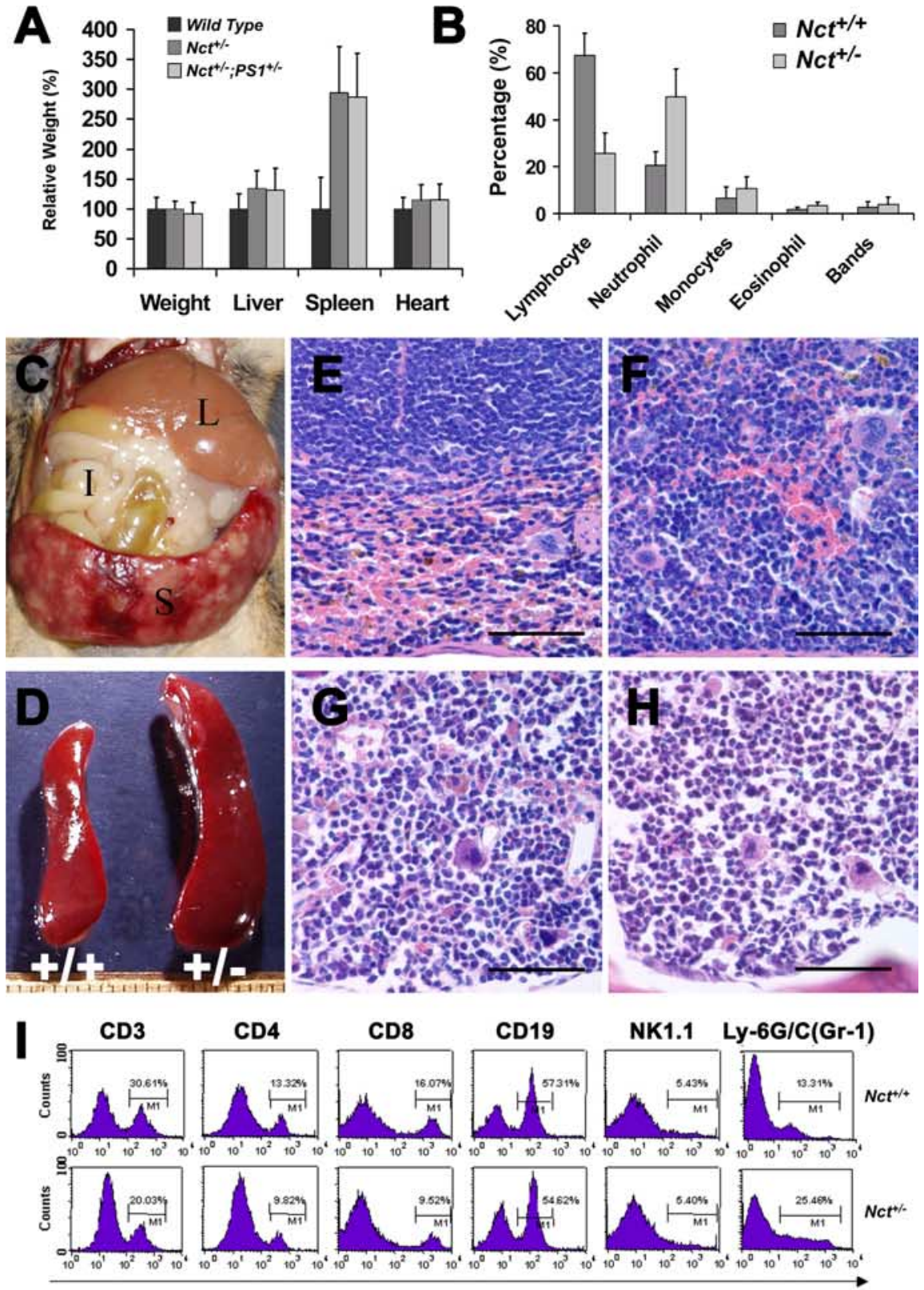

CD19
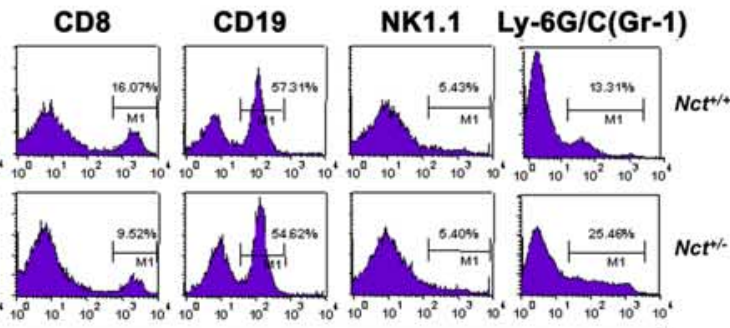

$10^{1} 10^{2}+10^{3} 10^{4}$
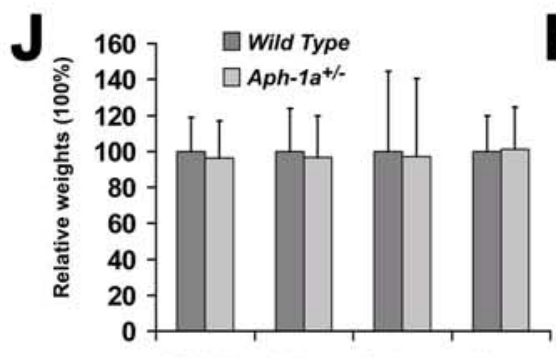

Weight Liver Spleen Heart
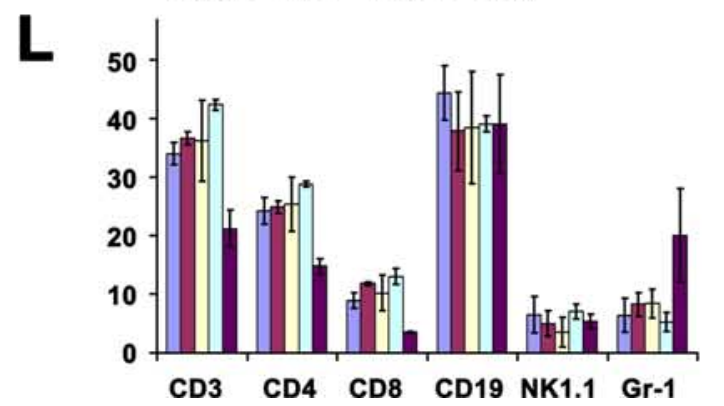

sions from $\mathrm{Nct}^{+/-}$mice revealed normal percentages of B and NK cells, decreased percentages of $\mathrm{T}$ cells, and increased percentages of granulocytes compared with that of $\mathrm{Nct}^{+/+}$mice (Fig. 4I). Together, these data indicated that the splenomegaly observed in $\mathrm{Nct}^{+/-}$and $\mathrm{Nct}^{+/-} ; \mathrm{PSI}^{+/-}$ mice is caused by myeloid hyperproliferation and suppression of T-cell proliferation.

The risk of developing splenomegaly in mice appeared to be dependent on the level of $\gamma$-secretase, and there is a threshold of $\gamma$-secretase level for the development of this abnormality. Although a small percentage of old Aph-1a $a^{+/-}$mice (60 weeks or older) also showed enlargement of

Figure 4. $\mathrm{Nct}^{+/-}$mice exhibit abnormalities in spleen. $\boldsymbol{A}$, Comparison of the size of organs between $\mathrm{Nct}^{+/-}, \mathrm{Nct}^{+/-}$; $\mathrm{PS}^{+/-}$, and wild-type mice. The average weight of spleen in $\mathrm{Nct}^{+/-}$and $\mathrm{Nct}^{+/-} ; \mathrm{PS}^{+/-}$mice is approximately threefold larger than wild-type control mice. Wet weight of organs was determined immediate after necropsy. Samples were collected from $53 \mathrm{Nct}^{+/-}$mice, $35 \mathrm{Nct}^{+/-} ; \mathrm{PS}^{+/-}$mice, and 66 agematched wild-type controls ( $p<0.0001$ ). B, Cell counts of peripheral blood; percentage of various cell types from $\mathrm{Nct}^{+/-}$ $(n=8)$ and $\mathrm{Nct}^{+/+}(n=8)$ mice are plotted $(p=0.01)$. C, The spleen can weigh $>2 \mathrm{~g}$ in some $\mathrm{Nct}^{+/-}$mice. Organs indicated are liver (L), intestine (I), and spleen (S). D, Examples of spleens from an $\mathrm{Nct}^{+/-}$(right) and its littermate $\mathrm{Nct}^{+/+}$mice (left) at 56 weeks of age. $\boldsymbol{E}, \boldsymbol{F}$, Section $(10 \mu \mathrm{m})$ of spleen from an $\mathrm{Nct}^{+/-}$mouse $(\boldsymbol{F})$ and an $\mathrm{Nct}^{+/+}$littermate $(\boldsymbol{E})$ at 51 weeks of age stained with hematoxylin and eosin. Note that subcapsular red pulp is expanded and filled almost exclusively by granulocytes and granulocyte precursors in $\mathrm{Nct}^{+/-}$mouse $(\boldsymbol{F})$, whereas in spleen of $\mathrm{Nct}^{+/+}$mouse, normal subcapsular red pulp with abundant red blood cells and normal white pulp (top half of image) are observed (60X). Scale bars, $50 \mu \mathrm{m}$. $\mathbf{G}, \boldsymbol{H}$ Section $(10 \mu \mathrm{m})$ of bone marrow from an $\mathrm{Nct}^{+/-}$mouse $(\boldsymbol{H})$ and a wild-type mouse $(\boldsymbol{G})$ at 51 weeks of age stained with hematoxylin and eosin; note that bone marrow from $\mathrm{Nct}^{+/-}$ mouse composed almost exclusively of granulocyte precursors with irregular segmented nuclear morphology $(\boldsymbol{H})$. The bone marrow from wild-type mouse showed ample erythroid precursors with more regularly rounded nuclei $(\boldsymbol{G})(60 \times)$. Scale bars, $50 \mu \mathrm{m} . \mathrm{I}$, Phenotypic analysis of splenocytes from $\mathrm{Nct}^{+/+}$and $\mathrm{NCt}^{+/-}$mice. Single splenocyte suspensions were prepared and stained with antibodies indicated. The cells were then analyzed using FACSCalibur and CELLQuest software. Note that the percentage of T-cell population is decreased, whereas granulocytes are increased in spleen of $\mathrm{Nct}^{+/-}$mice.J, Comparison of the size of organs between $\mathrm{Aph}-1 a^{+/-}$and wild-type mice at older than 60 weeks of age or younger. Samples were collected from $25 \mathrm{Aph}-1 \mathrm{a}^{+/-}$mice and 48 age-matched wildtype controls. $K$, Comparison of the size of organs between Aph$1 a^{+/-}, \mathrm{PS}^{+/-}$, and wild-type mice at older than 60 weeks of

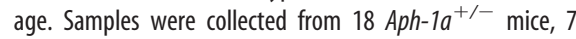
$\mathrm{PS}^{+/-}$mice, and 18 age-matched wild-type controls. L, Analysis of splenocytes from young $\mathrm{Aph}-1 \mathrm{a}^{+/-}, \mathrm{Nct}^{+/-}, \mathrm{Nct}^{+/-}$; $\mathrm{PS}^{+/-}$, and wild-type mice $(n=4$ for each genotype, 3 months of age) compared with aged Aph-1a ${ }^{+/-}$mice at 15 months of age $(n=4)$. Note that the percentage of T-cell population is decreased, whereas percentage of granulocytes is increased only in the spleen of aging $\mathrm{Aph}-1 \mathrm{a}^{+/-}$mice. 


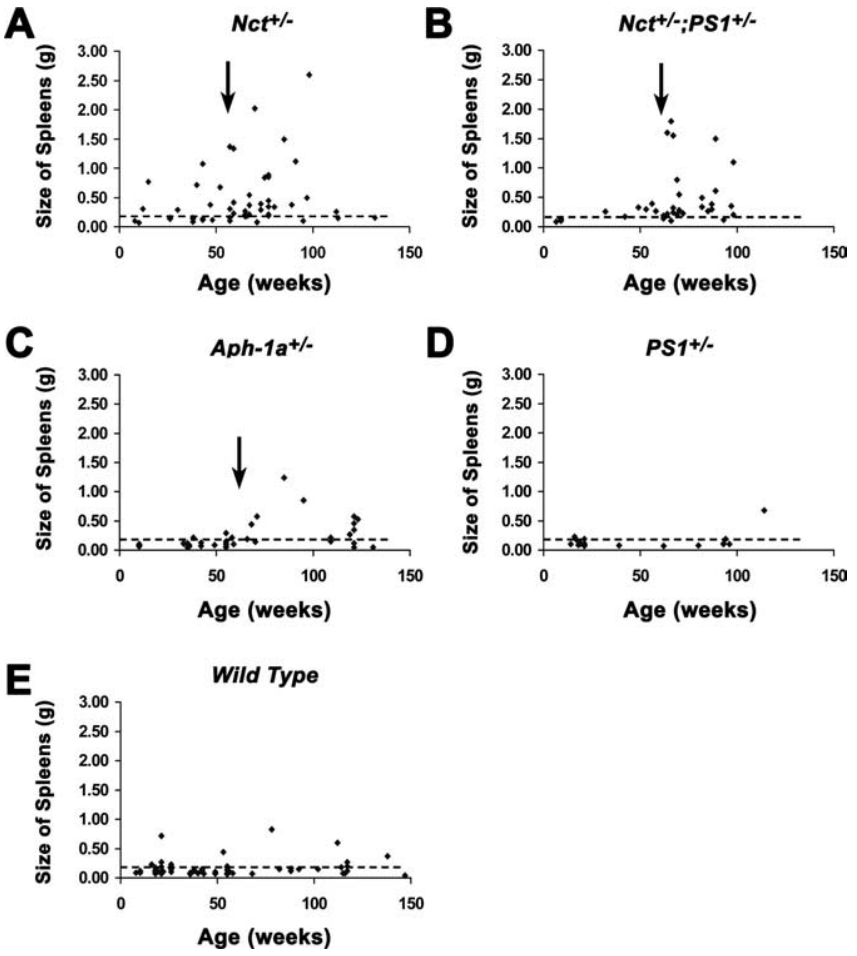

Figure 5. Sizes of spleens in different lines of mice. The weights of spleen were plotted against the age of the mice. Spleen in mice with splenomegaly weighed $>0.2 \mathrm{~g}$, which is more than twofold compared with that of wild-type mice. Note that risk of developing splenomegaly is dramatically increased in $\mathrm{Nct}^{+/-}, \mathrm{Nct}^{+/-}, \mathrm{PST}^{+/-}$, and $\mathrm{Aph}-1 \mathrm{a}^{+/-}$mice that are $>1$ year of age (arrow) but not in $\mathrm{SS}^{+/-}$mice even at older ages.

spleen, splenomegaly is rarely observed in $P S 1^{+/-}$mice (Fig. $4 J, K)$. Flow cytometric analysis of spleen cell suspensions from aged Aph-1 $a^{+/-}$mice (15 months of age) revealed similar changes in myeloid and lymphocytes as we observed in $\mathrm{Nct}^{+/-}$ and $\mathrm{Nct}^{+/-} ; \mathrm{PS1}^{+/-}$mice, such as normal percentages of $\mathrm{B}$ and NK cells, decreased percentages of $T$ cells, and increased percentages of granulocytes (Fig. $4 L$ ). Interestingly, the risk of developing splenomegaly are correlated with the levels of $\gamma$-secretase in mice and appeared to be age dependent (Fig. 5). Most cases of enlarged spleen were observed in mice older than 60 weeks of age. Supporting this view, flow cytometric analysis of splenocytes from young $\mathrm{Aph}-1 \mathrm{a}^{+/-}, \mathrm{Nct}^{+/-}$, or $\mathrm{Nct}^{+/-} ; \mathrm{PS1}^{+/-}$mice at 3 months of age revealed no differences compared with that of wild-type mice (Fig. $4 L$ ). Together, our findings suggest that $\gamma$-secretase is critical in regulating myeloid and lymphocyte development, and reduction of the $\gamma$-secretase to $>30 \%$ will increase the risk of developing abnormal proliferation of granulocytes in mice.

\section{$\mathrm{Nct}^{+/-}$mice perform normally in tasks that assess memory and anxiety}

Finally, we also tested the impact of reduction of $\gamma$-secretase up to $50 \%$ on CNS function. A series of behavioral studies performed on 3-month-old mice revealed that $\mathrm{Nct}^{+/-}$mice exhibit equivalent learning behavior compared with $\mathrm{Nct}^{+/+}$mice in the Morris water maze, which assesses spatial reference memory (Fig. 6A). In addition, compared with $\mathrm{Nct}^{+/+}$mice, $\mathrm{Nct}^{+/-}$mice showed similar latencies and distance to reach the platform in a radial water maze task and in a serial reversal task (data not shown). Moreover, no differences in anxiety were observed between wild- type and $\mathrm{Nct}^{+/-}$mice as assessed in an open-field task (Fig. $6 \mathrm{~B}$ ) and on the elevated plus maze (Fig. 6C).

We also perform behavioral test on older mice (6 months of age). However, because the Morris water maze test will cause discomfort to $\mathrm{Nct}^{+/-}$mice that developed skin lesions, we used the Y-maze task as an independent method to assess spatial working memory in older mice (6 months of age). There was no significant difference between the $\mathrm{Nct}^{+/-}$mice and the wild-type group with respect to spontaneous alternation and total number of entries (Fig. 6D). Together, these data indicate that the reduction in $\gamma$-secretase activity to $50 \%$ does not have an adverse effect on CNS functions in these animals, including learning and memory.

\section{Discussion}

\section{$\gamma$-Secretase as a therapeutic target for AD}

Pharmacological inhibition of $\gamma$-secretase has long been considered as an attractive anti-amyloid therapy for AD. However, exploring the therapeutic potential of $\gamma$-secretase inhibitors is hindered by the fact that the efficacy in attenuation of $\mathrm{A} \beta$ amyloidosis and the mechanism-based toxicity associated with chronic reduction of $\gamma$-secretase activity remains undefined. Here, we evaluated the effect on $\mathrm{A} \beta$ amyloidosis of global decrease of $\gamma$-secretase activity genetically during aging and demonstrated that $\mathrm{A} \beta$ amyloidosis is sensitive to the dosage of $\gamma$-secretase, supporting the view that $\gamma$-secretase is an attractive CNS therapeutic target for amelioration of $\mathrm{A} \beta$ amyloidosis in $\mathrm{AD}$. Moreover, whereas mice with strong reduction/inhibition of $\gamma$-secretase $(>50 \%)$ genetically $\left(\mathrm{Nct}^{+/-}\right.$or $\mathrm{Nct}^{+/-} ; \mathrm{PS1}^{+/-}$mice) develop skin abnormalities and SCC, mice with modest reduction of $\gamma$-secretase are relatively normal $\left(A p h-1 a^{+/-}\right.$or $P S 1^{+/-}$ mice), suggesting that beneficial effects in the CNS can be dissociated from the mechanism-based toxicities associated with reduction of $\gamma$-secretase. Our findings establish that an optimal level of inhibition of $\gamma$-secretase can be achieved (supplemental Fig. 2, available at www.jneurosci.org as supplemental material), indicating that modest pharmacological inhibition $(<30 \%)$ of $\gamma$-secretase is a reasonable therapeutic strategy in efforts to ameliorate $\mathrm{A} \beta$ amyloidosis in $\mathrm{AD}$.

Pharmacological inhibition of $\gamma$-secretase activity in vivo has been reported to cause untoward side effects (Milano et al., 2004; Wong et al., 2004), which have been interpreted as mechanismbased toxicity related to disturbance of the Notch signaling pathway by $\gamma$-secretase inhibitors. However, it is unclear whether current $\gamma$-secretase inhibitors are specific, i.e., only inhibiting $\gamma$-secretase activity. Moreover, discrepancies appear to exist between different inhibitors of $\gamma$-secretase; one inhibitor, BMS2999897, did not show the same side effects (Barten et al., 2005) as that of LY411575 (Milano et al., 2004; Wong et al., 2004). It is highly possible that phenotypes observed in mice treated with these inhibitors are not attributable to mechanism-based toxicity of inhibition of $\gamma$-secretase but rather to off-target side effects of these inhibitors. Our genetic approach to evaluate the efficacy and consequences of chronic reduction of $\gamma$-secretase demonstrate that mice with global genetic reduction of $\gamma$-secretase (down to $\sim 36 \%$ of that of wild-type mice) did not exhibit any reported toxicity associated with $\gamma$-secretase inhibitors in vivo (Milano et al., 2004; Wong et al., 2004), suggesting that side effects caused by some $\gamma$-secretase inhibitors can be attributed to off-target activities of these compounds. More importantly, our results establish a basis for setting a standard for evaluating any $\gamma$-secretase inhibitors for off-target and side effects of these drugs. 
A
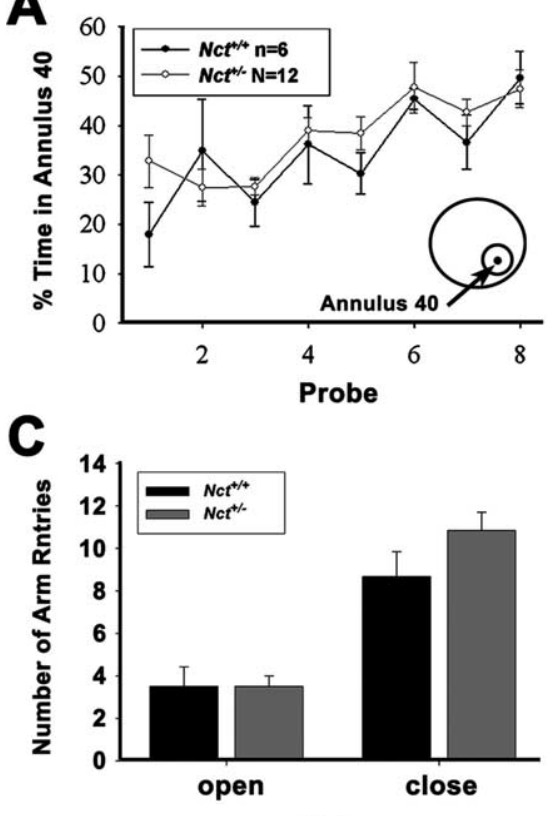

Arm

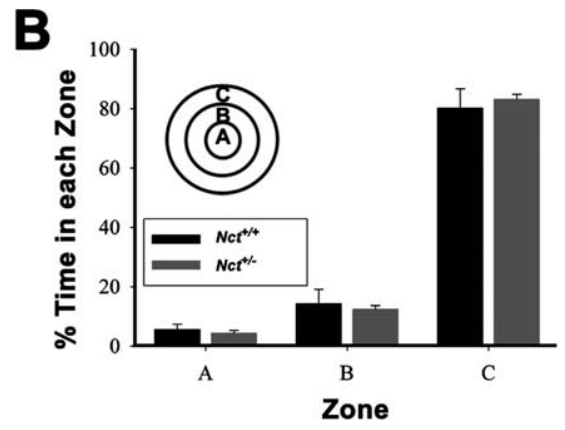

D

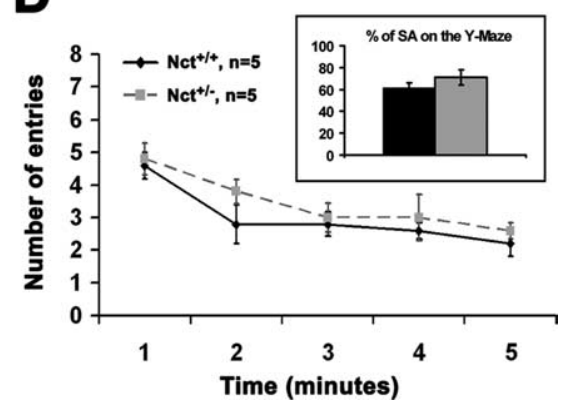

Figure 6. Normal cognition in $\mathrm{Nct}^{+/-}$mice. $\boldsymbol{A}$, Learning in the Morris water maze reference memory task was equivalent in wild-type and $\mathrm{NCt}^{+/-}$mice at 3 months of age as determined by the percentage of time spent in annulus 40 on the probe trial (40 cm diameter around the platform position; see inset). $\boldsymbol{B}, \boldsymbol{C}$, No difference in anxiety was observed between 3-month-old wild-type and $\mathrm{Nct}^{+/-}$mice as assessed in an open-field test as determined by the percentage of time spent in each zone $(\boldsymbol{B})$ and on the elevated plus maze as determined by the number of entries in closed and opened arm (C). D, Performance in Y-maze memory task was comparable between wild-type and $\mathrm{Nct}^{+/-}$mice at 6 months of age. There was no significant difference in spontaneous alternation (SA, inner box; $p=0.29$ ) and number across the sessions between two groups $(p=0.32$ ).

\section{$\gamma$-Secretase functions as a tumor suppressor}

Although it remains unclear as to the consequences of chronic reduction of $\gamma$-secretase activity in vivo, outcomes from studies of conditional deletion of PS in the forebrain were interpreted to support the view that partial loss of PS function in CNS may contribute to memory loss and neurodegeneration in PS-linked familial AD (Saura et al., 2004). To clarify the long-term chronic effects of reducing $\gamma$-secretase activity in vivo, we assessed $\mathrm{Nct}^{+/-}$ mice for pathological and behavioral abnormalities during development and aging. Although neither learning/memory impairment nor neurodegeneration in the CNS is observed in $\mathrm{Nct}^{+/-}$ mice, these mice with $50 \%$ reduction of $\gamma$-secretase activity exhibit increased risk for development of age-associated skin cancer. Although these findings do not support the notion that haploinsufficiency in $\gamma$-secretase activity is associated with memory impairment or neurodegeneration, they strongly support the view that $\gamma$-secretase functions as a tumor suppressor.

\section{$\boldsymbol{\gamma}$-Secretase play critical roles in hematopoiesis}

Other than skin tumors, another side effect of reducing levels of $\gamma$-secretase in mice is increased risk for development of splenomegaly characterized by hyperproliferation of granulocytes and reduction of T-cell populations, indicating that $\gamma$-secretase plays an important role in hematopoiesis. Consistent with the view that Notch signaling is required for lymphoid progenitors to initiate a T-cell fate development (Radtke et al., 1999; Tan et al., 2005), we found that the T-cell population is reduced in mice with enlarged spleen. However, unlike reports that mice treated with $\gamma$-secretase inhibitors showed suppressed CD8 ${ }^{+}$T-cell proliferation, no significant difference in $\mathrm{CD} 4{ }^{+}$to $\mathrm{CD} 8{ }^{+} \mathrm{T}$-cell ratios is observed in different lines of mice with genetic reduction of $\gamma$-secretase. In contrast, our observations are consistent with the finding that reduction of Notch1 was not correlated to $\mathrm{CD}^{+}{ }^{+}$verses $\mathrm{CD}^{+}{ }^{+} \mathrm{T}$-cell fate decision (Wolfer et al., 2001), indicating that the suppression of $\mathrm{CD} 8{ }^{+} \mathrm{T}$-cell development in mice treated with $\gamma$-secretase inhibitor is not attributable to inhibition of $\gamma$-secretase activity but rather to off-target side effects of these $\gamma$-secretase inhibitors. These findings further emphasize the importance for establishing a standard for evaluating any $\gamma$-secretase inhibitors using a genetic approach.

Our observation that a decrease in $\gamma$-secretase activity leads to an enlarged spleen by promoting the proliferation of granulocytes in mice implicate that $\gamma$-secretase activity plays a critical role in modulating the development of myeloid lineages. However, because inflammation alters normal leukocyte production by promoting granulopoiesis over lymphopoiesis (Ueda et al., 2005), it is also possible that splenomegaly occurring in $\mathrm{Nct}^{+/-}$ mice is caused by hyperinflammatory changes related to ruptured skin cysts and invasive tumors. However, we found that splenomegaly also occurred in Aph-1 $a^{+/-}$ mice that show no significant risk of developing skin tumors, indicating that the increased myeloid proliferation is more likely attributable to mechanism-based toxicity of reducing $\gamma$-secretase in mice. Consistent with this view is recent findings that mice heterozygous for PS1 and homozygous for PS2 $\left(P S 1^{+/-} ; P S 2^{-/-}\right)$develop splenomegaly with increased granulocyte proliferation in the absence of cutaneous lesions ( $\mathrm{Qy}-$ ang et al., 2004). Interestingly, that the risk of developing splenomegaly is dependent on the threshold level of $\gamma$-secretase further supports the view that modest reduction of $\gamma$-secretase is relatively safe for mice, as observed in $P S 1^{+/-}$ mice, and provides benefits in the CNS but limits mechanismbased toxicities in the periphery.

\section{Molecular pathways common to neurodegenerative diseases} and cancer

The chronic reduction of $\gamma$-secretase activity globally attenuates $\mathrm{A} \beta$ amyloidosis but increases the risk of developing skin cancer indicate that $\gamma$-secretase plays a pivotal role in both $\mathrm{AD}$ and cancer, two major age-associated diseases of the elderly. Recent epidemiological studies suggest that an inverse relationship exists between $\mathrm{AD}$ and cancer (Roe et al., 2005). These findings provoked the notion that common molecular mechanisms may underlie the development of AD and cancer. Our discoveries offer the possibility that $\gamma$-secretase is one potential mechanism that underlies such an inverse relationship between cancer and AD. Many chronic diseases are the result of alteration of gene dosage of specific transcription factor or tumor suppressor gene (Birchler et al., 2005). Consistent with this view that alteration of specific gene dosage can impact on several different disorders are recent findings that $D J-1$, associated with autosomal recessive early-onset Parkinson's disease (Bonifati et al., 2003), serves as an oncogene that regulates the tumor suppressor PTEN (phospha- 
tase and tensin homolog) (Kim et al., 2005), and superoxide dismutase 1, associated with autosomal dominant familial amyotrophic lateral sclerosis (Rosen et al., 1993), when deleted in mice induces liver carcinoma (Elchuri et al., 2004). The realization that common molecular pathways are shared between neurodegenerative diseases and cancer emphasizes the importance of understanding the physiological roles of these molecular entities and of developing rational therapeutic strategies that would minimize the potential mechanism-based toxicities.

\section{Summary}

Because no effective mechanism-based therapies are currently available, pharmacological inhibition of $\gamma$-secretase has long been considered as an attractive anti-amyloid therapy for $\mathrm{AD}$. We found that beneficial effects in the CNS can outweigh the mechanism-based toxicities associated with reduction of $\gamma$-secretase and establish that an optimal level of reduction in $\gamma$-secretase can be achieved (supplemental Fig. 2, available at www.jneurosci.org as supplemental material), indicating that modest pharmacological inhibition $(<30 \%)$ of $\gamma$-secretase can serve as an effective therapeutic strategy in efforts to ameliorate $\mathrm{A} \beta$ amyloidosis in $\mathrm{AD}$. However, although our results support the view that there is a reasonable therapeutic window for pharmacological inhibition of $\gamma$-secretase, future studies should nevertheless be alert to mechanism-based toxicity associated with $\gamma$-secretase inhibitors.

\section{References}

Allman D, Punt JA, Izon DJ, Aster JC, Pear WS (2002) An invitation to T and more: Notch signaling in lymphopoiesis. Cell 109:S1-S11.

Andreasson KI, Savonenko AV, Vidensky S, Goellner JJ, Zhang Y, Shaffer A, Kaufmann WI, Worley PF, Isakson P, Markowska AL (2001) Agedependent cognitive deficits and neuronal loss cyclooxygenase-2 transgenic mice. J Neurosci 21:8198-8209.

Artavanis-Tsakonas S, Rand MD, Lake RJ (1999) Notch signaling: cell fate control and signal integration in development. Science 284:770-776.

Barten DM, Guss VL, Corsa JA, Loo A, Hansel SB, Zheng M, Munoz B, Srinivasan K, Wang B, Robertson BJ, Polson CT, Wang J, Roberts SB, Hendrick JP, Anderson JJ, Loy JK, Denton R, Verdoorn TA, Smith DW, Felsenstein KM (2005) Dynamics of $\beta$-amyloid reductions in brain, cerebrospinal fluid, and plasma of $\beta$-amyloid precursor protein transgenic mice treated with a $\gamma$-secretase inhibitor. J Pharmacol Exp Ther 312:635-643.

Birchler JA, Riddle NC, Auger DL, Veitia RA (2005) Dosage balance in gene regulation: biological implications. Trends Genet 21:219-226.

Bonifati V, Rizzu P, van Baren MJ, Schaap O, Breedveld GJ, Krieger E, Dekker MC, Squitieri F, Ibanez P, Joosse M, van Dongen JW, Vanacore N, van Swieten JC, Brice A, Meco G, van Duijn CM, Oostra BA, Heutink P (2003) Mutations in the DJ-1 gene associated with autosomal recessive early-onset parkinsonism. Science 299:256-259.

Brayton C, Justice M, Montgomery CA (2001) Evaluating mutant mice: anatomic pathology. Vet Pathol 38:1-19.

Brittan M, Wright N (2002) Gastrointestinal stem cells. J Pathol 197:492-509.

Cai H, Wang Y, McCarthy D, Wen H, Borchelt DR, Price DL, Wong PC (2001) BACE1 is the major beta-secretase for generation of Abeta peptides by neurons. Nat Neurosci 4:233-234.

De Strooper B (2003) Aph-1, Pen-2, and Nicastrin with Presenilin generate an active gamma-Secretase complex. Neuron 38:9-12.

Elchuri S, Oberley TD, Qi W, Eisenstein RS, Jackson Roberts L, Van Remmen H, Epstein CJ, Huang TT (2004) CuZnSOD deficiency leads to persistent and widespread oxidative damage and hepatocarcinogenesis later in life 24:367-380.

Hardy J, Selkoe DJ (2002) The amyloid hypothesis of Alzheimer's disease: progress and problems on the road to therapeutics. Science 297:353-356.

Jankowsky JL, Xu G, Fromholt D, Gonzales V, Borchelt DR (2003) Environmental enrichment exacerbates amyloid plaque formation in a transgenic mouse model of Alzheimer disease. J Neuropathol Exp Neurol 62:1220-1227.
Kim RH, Peters M, Jang Y, Shi W, Pintilie M, Fletcher GC, DeLuca C, Liepa J, Zhou L, Snow B (2005) DJ-1, a novel regulator of the tumor suppressor PTEN. Cancer Cell 7:263-273.

Li J, Fici GJ, Mao CA, Myers RL, Shuang R, Donoho GP, Pauley AM, Himes CS, Qin W, Kola I, Merchant KM, Nye JS (2003a) Positive and negative regulation of the gamma-secretase activity by nicastrin in a murine model. J Biol Chem 278:33445-33449.

Li T, Ma G, Cai H, Price DL, Wong PC (2003b) Nicastrin is required for assembly of presenilin $/ \gamma$-secretase complexes to mediate notch signaling and for processing and trafficking of $\beta$-amyloid precursor protein in mammals. J Neurosci 23:3272-3277.

Li YM, Lai MT, Xu M, Huang Q, DiMuzio-Mower J, Sardana MK, Shi XP, Yin KC, Shafer JA, Gardell SJ (2000) Presenilin 1 is linked with gammasecretase activity in the detergent solubilized state. Proc Natl Acad Sci USA 97:6138-6143.

Luo WJ, Wang H, Li H, Kim BS, Shah S, Lee HJ, Thinakaran G, Kim TW, Yu G, Xu H (2003) PEN-2 and APH-1 coordinately regulate proteolytic processing of presenilin 1. J Biol Chem 278:7850-7854.

Ma G, Li T, Price DL, Wong PC (2005) APH-la is the principal mammalian APH-1 isoform present in $\gamma$-secretase complexes during embryonic development. J Neurosci 25:192-198.

Milano J, McKay J, Dagenais C, Foster-Brown L, Pognan F, Gadient R, Jacobs RT, Zacco A, Greenberg B, Ciaccio PJ (2004) Modulation of notch processing by $\gamma$-secretase inhibitors causes intestinal goblet cell metaplasia and induction of genes known to specify gut secretory lineage differentiation. Toxicol Sci 82:341-358.

Nicolas M, Wolfer A, Raj K, Kummer JA, Mill P, van Noort M, Hui CC, Clevers H, Dotto GP, Radtke F (2003) Notch1 functions as a tumor suppressor in mouse skin. Nat Genet 33:416-421.

Proweller A, Tu L, Lepore JJ, Cheng L, Lu MM, Seykora J, Millar SE, Pear WS, Parmacek MS (2006) Impaired notch signaling promotes de novo squamous cell carcinoma formation. Cancer Res 66:7438-7444.

Qyang Y, Chambers SM, Wang P, Xia X, Chen X, Goodell MA, Zheng H (2004) Myeloproliferative disease in mice with reduced presenilin gene dosage: effect of gamma-secretase blockage. Biochemistry 43:5352-5359.

Radtke F, Wilson A, Stark G, Bauer M, van Meerwijk J, MacDonald HR, Aguet M (1999) Deficient T cell fate specification in mice with an induced inactivation of Notch1. Immunity 10:547-558.

Roe CM, Behrens MI, Xiong C, Miller JP, Morris JC (2005) Alzheimer disease and cancer. Neurology 64:895-898.

Rosen DR, Siddique T, Patterson D, Figlewicz DA, Sapp P, Hentati A, Donaldson D, Goto J, O’Regan JP, Deng H-X, Rahmani Z, Krizus A, McKenna-Yasek D, Cayabyab A, Gaston SM, Berger R, Tanzi RE, Halperin JJ, Herzfeldt B, Van den Bergh R, et al. (1993) Mutations in Cu/Zn superoxide dismutase gene are associated with familial amyotrophic lateral sclerosis. Nature 362:59-62.

Saura CA, Choi SY, Beglopoulos V, Malkani S, Zhang D, Rao BS, Chattarji S, Kelleher III RJ, Kandel ER, Duff K, Kirkwood A, Shen J (2004) Loss of presenilin function causes impairments of memory and synaptic plasticity followed by age-dependent neurodegeneration. Neuron 42:23-36.

Savonenko A, Xu GM, Melnikova T, Morton JL, Gonzales V, Wong MPF, Price DL, Tang F, Markowska AL, Borchelt DR (2005) Episodic-like memory deficits in the APPswe/PS1dE9 mouse model of Alzheimer's disease: relationships to $\beta$-amyloid deposition and neurotransmitter abnormalities. Neurobiol Dis 18:602-617.

Tan JB, Visan I, Yuan JS, Guidos CJ (2005) Requirement for Notch1 signals at sequential early stages of intrathymic T cell development. Nat Immunol 6:671-679.

Tanzi RE, Bertram L (2005) Twenty years of the Alzheimer's disease amyloid hypothesis: a genetic perspective. Cell 120:545-555.

Thinakaran G, Borchelt DR, Lee MK, Slunt HH, Spitzer L, Kim G, Ratovitsky T, Davenport F, Nordstedt C, Seeger M, Hardy J, Levey AI, Gandy SE, Jenkins NA, Copeland NG, Price DL, Sisodia SS (1996) Endoproteolysis of presenilin 1 and accumulation of processed derivatives in vivo. Neuron 17:181-190.

Ueda Y, Kondo M, Kelsoe G (2005) Inflammation and the reciprocal production of granulocytes and lymphocytes in bone marrow. J Exp Med 201:1771-1780

Vehmas AK, Borchelt DR, Price DL, McCarthy D, Wills-Karp M, Peper MJ, Rudow G, Luyinbazi J, Siew LT, Troncoso JC (2001) beta-Amyloid peptide vaccination results in marked changes in serum and brain Abeta levels 
in APPswe/PS1DeltaE9 mice, as detected by SELDI-TOF- based ProteinChip technology. DNA Cell Biol 20:713-721.

Weng AP, Aster JC (2004) Multiple niches for Notch in cancer: context is everything. Curr Opin Genet Dev 14:48-54.

Wolfer A, Bakker T, Wilson A, Nicolas M, Ioannidis V, Littman DR, Lee PP, Wilson CB, Held W, MacDonald HR, Radtke F (2001) Inactivation of Notch 1 in immature thymocytes does not perturb CD4 or CD8T cell development. Nat Immunol 2:235-241.

Wong GT, Manfra D, Poulet FM, Zhang Q, Josien H, Bara T, Engstrom L, Pinzon-Ortiz M, Fine JS, Lee HJ, Zhang L, Higgins GA, Parker EM (2004) Chronic treatment with the gamma-secretase inhibitor LY411,575 inhibits beta-amyloid peptide production and alters lymphopoiesis and intestinal cell differentiation. J Biol Chem 279:12876-12882.
Wong PC, Zheng H, Chen H, Becher MW, Sirinathsinghji DJ, Trumbauer ME, Chen HY, Price DL, Van der Ploeg LH, Sisodia SS (1997) Presenilin 1 is required for Notchl and DIIl expression in the paraxial mesoderm. Nature 387:288-292.

Wong PC, Li T, Price DL (2005) Neurobiology of Alzheimer's disease. Basic neurochemistry, Ed 7. Baltimore: Lippencott Williams \& Wilkins.

Xia X, Qian S, Soriano S, Wu Y, Fletcher AM, Wang XJ, Koo EH, Wu X, Zheng $\mathrm{H}$ (2001) Loss of presenilin 1 is associated with enhanced beta-catenin signaling and skin tumorigenesis. Proc Natl Acad Sci USA 98:10863-10868.

Xu G, Gonzales V, Borchelt DR (2002) Rapid detection of protein aggregates in the brains of Alzheimer patients and transgenic mouse models of amyloidosis. Alzheimer Dis Assoc Disord 16:191-195. 